\title{
Governance and well-being in academia: The negative consequences of applying an agency theory logic in higher education
}

\author{
Monica Franco-Santos ${ }^{1}$ \\ Cranfield University, Cranfield School of Management, \\ Cranfield, MK43 0AL, Bedfordshire, England \\ Email: monica.franco@cranfield.ac.uk \\ Tel: +44 (0) 1234751122 \\ Michael Nalick \\ Texas A\&M University, Mays Business School, \\ College Station, Texas 77843-4221, USA \\ Email: mnalick@mays.tamu.edu \\ Tel: +19798454851 \\ Pilar Rivera-Torres \\ Zaragoza University, \\ Faculty of Economics and Business Administration, \\ C/ Gran Via 2, 50005 Zaragoza, Spain \\ Email: privera@ unizar.es \\ Tel: +34976762094 \\ Luis Gomez-Mejia \\ Arizona State University \\ W.P. Carey School of Business \\ Main Campus, BA 397D, PO BOX 874006 \\ Tempe, AZ 85287-4006 \\ Email: luis.gomez-mejia@asu.edu
}

Tel: +1 4809650411

\footnotetext{
${ }^{1}$ Corresponding author
} 


\section{Authors' biography}

Monica Franco-Santos is a Senior Lecturer in the Cranfield School of Management at Cranfield University. Her research broadly focuses on organizational governance systems. In particular, her work examines the design, implementation, and use of performance measures, targets and rewards as well as the impact that these mechanisms have on behavior and decision-making.

Michael Nalick is a 5th-year doctoral candidate in the Mays Business School at Texas A\&M University. His research interests are in the field of strategy and governance with a particular focus on organizational reaction to social and institutional change and the study of values and personal experiences of organizational elites.

Pilar Rivera-Torres is an Associate Professor in the area of Commercialization and Market Research in the Department of Marketing Management and Market Research, Faculty of Economics and Business, at the Universidad de Zaragoza. Her research focuses on quantitative methods, in particular, econometric modeling (SEM).

Luis Gomez-Mejia is a Professor in the area of Management in Arizona State University. He has publishing more than 200 articles in the most prestigious management journals. He is ranked one of the most highly cited scholars (19,600 citations/Harzing.com-Google Scholar). $\mathrm{He}$ is a member of the Hall of Fame of the Academy of Management. His research ranges from executive compensation, international management, family business and strategy management.

\section{Acknowledgements}

We wish to express our appreciation to Professor Marc Goergen and three anonymous reviewers for their helpful and constructive comments. We also would like to thank those scholars who read earlier drafts of this paper and made valuable contributions including Geoff Martin, Michael Hitt and the participants of the Strategic Management Society Conference in Madrid 2014 and the Academy of Management in Vancouver 2015. The empirical work of this paper was also greatly facilitated by the Leadership Foundation for Higher Education in the UK, and the research project ECO2013-48496-C4-3-R, funded by the Spanish MECC. 


\title{
Governance and well-being in academia: The negative consequences of applying an agency theory logic in higher education
}

\begin{abstract}
This study examines the relationship between alternative university governance practices and staff well-being. Specifically, we investigate how people in academic and professional services roles are managed and how various governance mechanisms such as the use of performance measures and targets influence their sense of vitality and stress. Drawing from agency theory and stewardship theory research, we expected universities to align their governance practices to the nature of their employment roles to enhance well-being. Based on data collected in the UK, we find that for some academic roles there is a misalignment between the responsibilities and job demands and the way institutions govern people in such roles, which is shown to affect their well-being. Our results suggest that well-being responses to governance mechanisms change depending on the role an employee performs and the position he or she occupies. Interestingly, our data suggests that the governance and wellbeing experiences of academic leaders are more closely aligned to those of professional service leaders than with those of academics without leadership positions. Taken together, our investigation notes several shortcomings in the internal governance practices of higher education institutions that can have unexpected consequences and require close attention and further research.
\end{abstract}

\section{KEYWORDS}

Governance, management control systems, performance management, higher education, universities, academics, professional services 


\section{INTRODUCTION}

Management researchers have long recognized that it is beneficial for organizations to align their governance practices to the tasks and responsibilities of their employees (Adler and Borys, 1996; Adler and Chen, 2011; Burns and Stalker, 1961; Cardinal, 2001; Eisenhardt, 1985; Frey et al., 2013; Ouchi, 1979; Rousseau, 1978). Scholars have premised this contention on the notion that the characteristics of an employee's work environment (i.e., autonomy, task identification, variety and feedback) affect the nature of the employment contract, including its obtainability and the stated utility of the desired rewards (Eisenhardt, 1989). As suggested by Davis et al., (1997), it is necessary for an organization to synchronize its governance practices to meet particular conditions of the organization's employment roles. Failure to do so can have wide ranging negative implications for the employee's relationship with their organization (Caldwell et al., 2008; Miller et al., 2002).

While this notion of governance-employee alignment is endlessly discussed in the management literature (Hernandez, 2012), whether this guidance is observed in public institutions that have recently transitioned their governance practices to reflect more of a 'private sector business-like' governance approach, such as the case in higher education, is uncertain (Kezar and Eckel, 2004). Over the last twenty plus years, reform-minded institutions in Western societies have instigated sweeping institutional changes in the way universities conduct their internal governance practices (Birnbaum, 2004; Decramer et al., 2012). This governance reform movement has long advocated for more 'accountability' and 'transparency' in public sector investments for higher education (Barry et al., 2001; Burrows, 2012; Martin, 2012; Zusman, 2005). As a result of these pressures, a series of government policies have been implemented in countries such as the UK (Bryson, 2004), the US (Zusman, 2005), the Netherlands (Schimank, 2005), Finland (Kallio and Kallio, 2014; Kallio et al., 2016), Australia (Field, 2015), and New Zealand (Waitere et al., 2011). 
In most countries, these internal governance changes have taken place alongside a contentious debate regarding the role of faculty in higher education institutions. Political pressure has coerced many institutions to adopt measures that attempt to hold faculty more accountable for performance in areas such as teaching and scholarship. For example, over the last few decades, the performance of UK faculty has been subject to national evaluation exercises that use performance measures and targets (Burrows, 2012; Franco-Santos et al., 2014; Morrish and Sauntson, 2016; ter Bogt and Scapens, 2012; Townley, 1997; Willmot, 1995). In the US, the situation is similar. For instance, the Texas A\&M Board of Regents developed business-like metrics for faculty productivity, reporting how much faculty "made" or "lost" for the university by calculating the number of courses taught, student enrolment in each course, and the amount of grant dollars awarded (USA Today, 2013). This trend towards more measured outcomes across academia has met fierce resistance. From 2012-2013, presidents of 12 of the 35 leading public research universities in the United States quit or had been fired due to performance-related disputes (USA Today, 2013). However, while such governance changes have been perceived as controversial, an increasing number of universities worldwide are still adopting 'business-like' governance practices that emphasize cost-effectiveness and centralized control including hard performance measures, targets and appraisals (Deem et al., 2007; McLendon et al., 2006; Milliken and Colohan, 2004; Rhoades 2005; Sporn, 1999; Toma, 2007).

As a result of these changes, there has been a polemic debate among academics and policy-makers regarding their overall effectiveness (McNay, 2015; Briner, 2015). This type of control-oriented governance is argued to better capture individual and department level performance compared to collegial-oriented governance practices that historically dominated universities (ter Bogt and Scapens, 2012; Deem et al., 2007). As a consequence of these mandated governance changes, the traditional collegial approach characterized by a disbursed 
or horizontal power structure, long-term mission, and an emphasis on self-organizing and self-management is being eroded (Birnbaum, 2004; Shore, 2008; Toma, 2007).

Scholars have begun to question the soundness of this governance transition (e.g., Morrish and Sauntson, 2016; Prichard and Willmott, 1997; Townley, 1997; Welpe et al., 2015; Willmott, 1995). Some have suggested that the stated goal in a corporate setting of maximizing shareholder value by meeting hard output measures is vastly different from the educational, research, and social fulfilment goals set by universities and their faculty (Schmidtlein and Berdahl, 2005). Other scholars contend that employment roles of educational faculty are misaligned with the hard performance measurement techniques found in control-oriented governance practices (Birnbaum, 2004; Kezar and Eckel, 2004). Our research attempts to provide further insight on this phenomenon. Drawing from existing governance theories, we investigate the extent to which people in different employment roles and positions working for UK universities experience the use of collegial or control governance practices, and the extent to which these experiences influence their well-being.

Considering the institutional pressures that are instigating governance changes in the higher education sector, this study facilitates a better understanding of the effects different internal governance practices have on the well-being of staff. Our investigation finds several shortcomings in the governance practices used by UK universities. In particular, the extent to which institutions of higher learning align their governance practices to their different employment roles is low. This misalignment appears to be having consequences for the wellbeing of staff, in particular of academic staff without leadership responsibilities. This finding is critical as staff well-being has been found to relate to increased learning (Duckworth and Cara, 2012), innovativeness (Huhtala et al., 2007), creativity (Ohly and Blewdow, 2015), helping behaviours (Grant and Kinman, 2014), socially responsible acts (Crilly et al., 2008), and productivity (Briner and Dewberry, 2007), all of which are considered drivers of success 
in education and research environments (Welpe et al., 2015). Therefore, our study provides evidentiary information that will hopefully enable further discussion regarding the design and implementation of internal governance systems in higher education institutions.

\section{BACKGROUND LITERATURE}

\section{Internal governance practices}

Originating from the ideological differences concerning the behaviour of man, as actors that can either be trusted and nurtured or opportunistic and controlled (Argyris, 1973a; Argyris, 1973b), there are two theories that are used to explain differences in the governance practices within organizations. The first theory is agency theory, which assumes that the two parties involved in a working relationship - a principal (e.g., owner or top management) and an agent (e.g., employee) - exhibit opportunistic or self-interested behaviours (Jensen and Meckling, 1976; Eisenhardt, 1989). These opportunistic behaviours give rise to the so-called agency problem, specifying that each party may have conflicting interests. Agents may focus on actions that optimize personal gains to the detriment of organizational goals. Thus, to minimize the agency problem inherent in any agency relationship, agency theorists propose that the principal should use monitoring (e.g., performance evaluation) and incentive mechanisms (e.g., performance related pay) to reduce agents' opportunistic behaviours, increasing their goal alignment (Fama, 1980; Fama and Jensen, 1983).

These practices have been described as control-oriented governance practices (hereafter labelled as 'control governance') as they attempt to regulate and control employees' behaviour and performance (Eisenhardt, 1988). Control governance practices are likely to be associated with formal levels of hierarchical structures with a clear differentiation of power and flows of information (Fama and Jensen, 1983; Hoskisson and Hitt, 1988). Additionally, these practices tend to limit employees' information freedoms and encourage short-term and 
financially driven decision-making (Eisenhardt, 1985; Fama, 1980). Agency theorists predict that the use of this type of governance approach will be beneficial for principals as well as enhance agents' well-being because it takes into consideration individuals' preferences (Heath, 2009).

The second theory that is often used to explain internal governance practices is stewardship theory (Davis et al., 1997). Stewardship theory contrasts with agency theory, as it is not concerned with controlling agents. This theory assumes that the interests of the two parties are already aligned so incentives and monitoring are not necessary for performance to occur (Hernandez, 2012; Tosi et al., 2003). According to stewardship theory, proorganizational, collectivistic behaviours have higher utility than self-serving, individualistic behaviours (Davis et al., 1997). Therefore, when people act as stewards they strive to protect and maximize the principals' interests by facilitating the delivery of organizational outcomes; and, in doing so, they also maximize their own interests and satisfaction.

Stewardship theory can be associated with collegial-oriented governance practices (hereafter labelled as 'collegial governance') that complement the notion of 'clan control' (Ouchi, 1979), including a disbursed power structure that emphasizes high trust, self-control and self-management. A collegial governance approach supports such a power structure by incorporating governance mechanisms focused on greater employee empowerment and wellbeing (Davis et al., 1997; Donaldson and Davis, 1991; Hernandez, 2012; Segal and Lehrer, 2012). Thus, elements of a collegial governance approach underscore inclusive and collaborative actions rather than 'top-down' command and control approaches. Collegial governance additionally emphasizes long-term performance defined primarily in nonfinancial terms rather than financial, such as pursuing the delivery of "an overarching mission, the furtherance of a distinctive concept, or a vision of some idealized future state or condition" (Graham and Organ, 1993, p. 490). 


\section{Internal governance practices and employment roles}

Previous research has prescribed the need for organizations to adapt their governance practices to the conditions associated with different employment roles (e.g., Adler and Borys, 1996; Adler and Chen, 2011; Davis et al., 1997; Eisenhardt, 1985; Frey, et al., 2013; Ouchi, 1977, 1979; Rousseau, 1978). The nature of employment roles can significantly influence both the efficacy of control governance and the organizational commitment and subjugation of self-interest associated with collegial governance. The distinctive nature of employment roles may be understood in terms of their task characteristics and their position within the organization.

Regarding their task characteristics, at one end of the spectrum are low structured roles distinguished by tasks that have low programmability. Eisenhardt (1989) defines programmability as "the degree to which appropriate behaviour by the agent can be specified in advance" (p. 62). Low structured roles are characterized by work assignments with high uncertainty that require operational flexibility and discretion. In these roles, the employee is expected to figure out the scope of the work. Job functions with low structured roles often encompass specialized tacit knowledge involving shared understanding and high inter-and intra-organizational collaboration to successfully complete assignments (Hess and Rothaermel, 2011; Turner and Makhija, 2006). Performance in low structured roles is difficult to measure and manage due to low observability, greater ambiguity, low outcome predictability, and the long-term orientation of these roles (Hernandez, 2012). Consequently, the nature of low structured roles tends to invalidate many forms of incentives and monitoring that are essential for the viability of control governance practices focused on minimizing opportunism and enhancing alignment (Eisenhardt, 1989; Frey et al., 2013; Levinthal, 1988; Ouchi, 1979). Therefore, most researchers suggest that using control practices for low 
structured roles may be inappropriate (Bouillon et al., 2006; Eisenhardt, 1985, 1989; Makri et al., 2006) or even dysfunctional (Eisenhardt, 1985, 1989; Frey, Homberg and Osterloh, 2013).

At the other end of the spectrum are high structured roles involving tasks that are highly programmable (Eisenhardt, 1989). Responsibilities in these roles are explicit and described in detail (Eisenhardt, 1985). Thereby in this type of roles, appropriate behaviours for performing well in a job are codified and specified in advance. An employment role in which the nature of the task is well specified tends to produce lower information asymmetries (Levinthal, 1988). As such, performance in high structured roles is more easily observable and measurable (i.e., it is time-bound and often produces tangible or 'hard' outcomes) (Eisenhardt, 1988), so control practices such as monitoring and incentives for minimizing opportunism are recommended (Eisenhardt, 1989).

Employment roles can also be described in terms of their position. Research often highlights the importance and particularities of leadership positions (e.g., Hambrick et al., 1998). When employees are selected for a leadership position (e.g., CEOs and heads of major subunits) the composition of their role changes. Despite their functional background, people in these roles become generalists whose main responsibilities involve the management of other people's work. Leadership roles are responsible for setting the goals that mark the direction of the organization, as well as accountable for their achievement (Hambrick et al., 1998; Simon, 1964). Furthermore, leadership roles have the authority to introduce or transform internal governance systems and structural forms aimed at facilitating organizational success (Hambrick et al., 1998). For example, leadership roles are usually in charge of establishing cost reduction programs, quality improvement programs, performance appraisals and incentive payments (Yukl, 2008).

From an agency theory perspective (Eisenhardt, 1989; Jensen and Meckling, 1976), it could be argued that leaders behave as principals acting on behalf of their dominant 
stakeholders when establishing internal governance mechanisms. Despite the apparent differences between leadership and non-leadership roles, it is interesting to note that the promoters of both agency theory (Eisenhardt, 1989; Jensen and Meckling, 1976) and stewardship theory (Davis et al., 1997; Hernandez, 2012) have not made distinctions regarding the most appropriate governance mechanisms for each group. These theories assume that their proposed governance practices are appropriate for all employees regardless of their position.

\section{HYPOTHESES}

\section{Employment roles, governance orientation and well-being in higher education}

Educational institutions worldwide are experiencing significant changes in their internal governance practices. As noted earlier, whereas a collegial governance approach was previously the norm in many institutions, now elements of control governance are firmly rooted in universities (Kezar and Eckel, 2004; Morrish and Sauntson, 2016; Welpe et al., 2015). Among other consequences, this transformation is likely to influence employees' wellbeing (Birnbaum, 2004; Gomez-Mejia and Balkin, 1992; Hernandez, 2012). Specifically, employees in low structured employment roles, such as those employees involved in research and teaching, may perceive this change as dysfunctional or misaligned with their scholarly values (Hernandez, 2012).

Employees in these roles are involved in tasks that require high autonomy, creativity, and operate in unstable environments (i.e., low structured roles). Occupants of such roles often perform activities under great constraints and face uncertain and highly variable performance outcomes. Individuals that perform well in these low structured roles tend to be described as highly skilled, knowledgeable, intrinsically driven and passionate for the overall mission of the university (Merton, 1996). People in academic roles usually have strong 
professional identities and values that highlight collaboration, trust, self-governance and stewardship (Hernandez, 2012; Kallio et al., 2016). Based on these conditions, academic employees may expect governance practices that are informal, flexible and enabling to support the nature of their employment role as well as their internalized scholarly values (Abernethy and Lillis, 1995; Burns and Stalker, 1961; Rousseau, 1978). Thus, people in academic roles may perceive a collegial approach as more appropriate, as it allows them to operate with minimal interference, build a trusting relationship with their institution and colleagues, and maintain their intrinsic motivation (Hernandez, 2012). Because collegial governance practices facilitate the type of tasks performed by people in academic roles and are more aligned with traditional academic values, we expect collegial governance practices will positively influence the well-being of academics. We therefore hypothesize:

\section{Hypothesis 1: For people in academic roles, collegial governance practices will be positively related to personal well-being.}

Conversely, when faculty perceives that they are being managed with control governance practices, this governance incongruity may engender a negative individual sentiment affecting their well-being (Davis et al., 1997). Specifically, previous research suggests that control governance practices may mollify intrinsic motivation due to their rigidity (Frey et al., 2013; Welpe et al., 2015). Increased rigidity decreases the autonomy and flexibility academics perceive as needed to fulfil their role responsibilities; and this reduced sense of autonomy and freedom may lead to feelings of dissatisfaction and demotivation, creating a lower sense of well-being (Adler and Borys, 1996; Caldwell et al., 2008; Cardinal, 2001; Deci and Ryan, 2010). Because people in academic roles often perform tasks that have low programmability and are strongly socialized into professional values that resemble stewardship beliefs, we posit that when they perceive they are being governed under control 
governance practices, they will express greater negativity. Thus, we suggest the following hypothesis.

Hypothesis 2: For people in academic roles, control governance practices will be inversely related to personal well-being.

While we expect employees in academic roles working in higher education institutions to react negatively to control governance practices, we do not anticipate the same negative reaction from professional services staff. In universities, professional services roles such as secretaries, marketing professionals or registry administrators usually involve relatively programmable and observable tasks with performance that can be more accurately evaluated and predicted. People performing these roles have not experienced the same professional indoctrination and socialization as people in academic roles. Many professional services individuals come from private sector organizations and are experienced working within formalized control governance structures.

Due to the characteristics of their roles and their backgrounds, professional services staff are more likely to respond positively when experiencing control governance practices. This could be the case because control governance practices provide them with direction, transparency, a more stable and predictable work environment, and clear expectations and responsibilities (Eisenhardt, 1989; Hernandez, 2012). Therefore, because control governance practices provide the appropriate direction and extrinsic motivation for staff whose job roles are characterized by programmed tasks with low uncertainty, we expect that people in these roles will react positively to higher levels of control governance (Eisenhardt, 1989). We thus suggest the following hypothesis. 
Hypothesis 3: For people in professional services roles, control governance practices will be positively related to personal well-being.

Because control governance practices provide a more stable and predictable environment in employment relationships with high structured roles, we believe that control governance practices will be more suitable for professional services staff than collegial governance practices. Adler and Chen (2011) suggest that there are negative implications when there is a misalignment between governance systems and certain employee characteristics. They argue staff involved in high programmability tasks face strain without a formalized environment. Collegial governance can be associated with less formalized contexts due to a diminished official power structure, which causes a sense of indeterminate expectations and undefined workplace boundaries. Less formalized power structures, such as those found in environments with collegial governance practices, can result in low authoritative direction, decreased transparency and increased peer evaluations, which can cause tension among some employees (Tuomela, 2005). Therefore, as control governance practices provide a sense of stability for people in professional services roles with high structured tasks, collegial governance practices may not satisfy their needs in the same manner, which may lead to less well-being.

Hypothesis 4: For people in professional services roles, collegial governance practices will be less positively related to well-being than control governance practices

The logic of our argument so far suggests that the employment role in terms of task structure will have an important effect in how different governance practices relate to staff well-being. However, as mentioned earlier, employment roles can also be described in terms of their position. Little attention has been paid to the understanding of how the position an 
employee occupies influences the way in which governance practices are experienced and the effect they have on the person's well-being.

People in university leadership positions (e.g., Vice-Chancellor, Pro-Vice Chancellors, Heads of faculties, schools and departments) are now responsible for setting direction and selecting the goals of their institutions (Buckland, 2009). They act on behalf of university stakeholders and are expected to define and implement the internal governance practices that facilitate the achievement of institutional goals. In recent years, there has been a shift from administration and political duties to "management of activity and of strategy" (Buckland, 2009, p. 531). Professional services leaders and academic leaders are now managing individuals and are accountable for performance results (Deem and Brehony, 2005; Deem, Hillyard and Reed, 2007). With this sense of accountability comes the need to control and be in control (Deem et al., 2007).

Managerial responsibilities become part of the day-to-day job of most academics moving into leadership positions. These management tasks usually overshadow their scholarly endeavours and ultimately define their role behaviour. Over time, the needs and experiences of academic leaders become more similar to those of professional services leaders than to those of their fellow scholars. For them, control practices are likely to be perceived as useful and relevant because they provide information and incentives to help encourage the performance of others. Nevertheless, due to their backgrounds and fundamental knowledge of academic work, they also value the benefits that collegial governance practices can bring. Thus, following this logic, we posit that the relationship between both governance practices and well-being will be positive for people in leadership positions.

Hypothesis 5: For people in leadership positions, both collegial and control governance practices will be positively related to their personal 
well-being regardless of the nature of their task structure.

\section{METHODS}

\section{Research setting, research process and sample selection}

The population for this study consists of staff working in UK universities. Over the last decades, the UK university sector has undergone a significant transformation concerning the way institutions implement their internal governance practices (Pollitt, 1987). As shown in previous research (e.g., Bolden et al., 2012), some universities function in a 'business-like' way (with a high emphasis on control, accountability and financial efficiency), whilst others continue to be run according to the collegial and high-trust traditional academic values system. This diversity is particularly important for our research as it provides the variability required for the examination of internal governance practices. It must be noted, that the work presented here forms part of a larger study involving mix research methods, which aim was to explain the governance mechanisms currently being used in UK universities (Authors, 2014). The data used in this research has been extracted from the survey of this larger study.

The survey was conducted in the last three months of 2012. It was addressed to a sample frame of 3,650 employees working in the UK's 162 universities representing approximately 1 percent of the population (HESA, 2012). We adopted a stratified random sampling process to develop our sample frame. Within each university, we focused on staff working for the vice-chancellor's office and central services (e.g., states, IT), and on staff employed at different parts of the institutions. We made special efforts to include people from four schools or faculties (management/business, education, math, and performing arts/cultural studies) to increase the variability of responses but allow for potential controls according to the various disciplines. Information about the individuals included in our sample frame came from publicly available data (e.g., names, job titles and email addresses). Some examples of 
job roles included in our work are: Lecturers, Senior Lecturers, Researchers, Professors, Deans or Heads of Schools/Faculty, Pro-Vice Chancellors, Director of Finance, Director of HR, and Administrative Support. We sent an email to our sample frame individuals inviting them to participate, along with the web-link to our survey. These individuals also received two follow-up messages. In total, we received 1,342 survey responses. After cleaning the data, we extracted 1,017 usable responses. However, after discarding responses that had missing information in key items used in this research, we obtained 975 valid responses (27 percent response rate). Our responses came from 141 universities, representing 87 percent of the overall UK university sector. In Table 1 we present the descriptive information of our survey respondents.

\section{INSERT TABLE 1 ABOUT HERE}

\section{Measures}

The literature was thoroughly examined to develop survey items capable of measuring our constructs: Control governance, collegial governance and employee well-being. We also conducted a series of interviews with key informants (mainly academics and senior staff from seven different UK universities) to refine the wording of our survey items and ensure their relevance and validity in the context of UK universities (Authors, 2014). Table 2 presents the items used to measure each of our constructs.

INSERT TABLE 2 ABOUT HERE 


\section{Exogenous variables}

Control governance practices. We created a multi-item scale to measure this construct. We examined agency theory research (e.g., Eisenhardt, 1989; Baiman, 1982) and extracted the key mechanisms highlighted as essential for aligning the interests of principals and agents at the lower levels of an organization. The key mechanisms proposed by agency theorists for the governance of organizations are: monitoring through performance measures and targets and performance-contingent compensation (Eisenhardt, 1989; Baiman, 1982). Based on these insights, we developed a seven-point Likert-type scale assessing the extent to which individuals perceived these governance mechanisms were being used in their universities. Our scale ranged from 1 "strongly disagree" to 7 "strongly agree". Table 2 provides the full text, description and background literature of the items used and Table 3 presents our descriptive statistics. In our Appendix (Table B), detailed information about the validity and reliability of this measure is presented.

Collegial governance practices. To measure this construct, we reviewed previous stewardship theory research (e.g., Davis et al., 1997a; Hernandez, 2012; Segal and Lehrer, 2012) and extracted suggestions from this literature that pertained to governance mechanisms. Stewardship theory suggests governance mechanisms that encourage participation, communication, resource provision, recognition of excellence, and continuous learning and autonomy. Using previous research conducted on UK universities (e.g., Bolden et al., 2012; Franco-Santos et al., 2014; ter Bogt and Scapens, 2012) and a set of interviews with key informants, we contextualized these mechanisms and created a seven-point Likert-type scale. The scale had six items ranging from 1 "strongly disagree" to 7 "strongly agree". Table 2 provides the full text of the items used for this measure and Table 3 the descriptive statistics. 
In our Appendix (Table B), detailed information about the validity and reliability of this measure is presented.

Employment role. For assessing employment roles, we created four different groups. In our survey, we used a categorical variable and every respondent was asked to select the group that best reflected his or her role. Our first group represented academic roles without leadership responsibilities. This group included traditional scholarly roles such as researchers, lecturers and professors without leadership responsibilities. People in these roles are expected to deliver highly diverse and abstract goals such as research excellence, education excellence, and societal contributions. The fulfilment of these goals involves tasks with a long-term orientation, vague or unknown 'means-ends connections', high uncertainty and low programmability (Campbell, 1988; Eisenhardt, 1988; March and Simon, 1958). Academic roles are 'low structured' in nature so we used them to designate this variable. In our tables, we designate this group using the abbreviation 'AC'. Our second group was formed by professional services roles without leadership responsibilities such as secretaries, registry officers, human resource or marketing professionals. People in these roles are expected to perform administrative tasks, mainly involving activities that are short-term with a low degree of uncertainty and high programmability. These professional services roles were used to represent 'high structured' roles. In our tables, we designate this group using the abbreviation 'PS'. The third and fourth groups in our analysis were formed by university leaders including academic leaders (e.g. Vice-Chancellor, Pro-Vice Chancellor and Heads of Schools, Faculties and Departments) and professional services leaders (e.g., Finance Director, Directors of Professional Services of Schools and Faculties). The group of academic leader roles is designated with the abbreviation 'ACL' in our tables; in the case of professional services leader roles we use 'PSL'. Our group classification is reflected in Figure 1. 


\section{INSERT FIGURE 1 ABOUT HERE}

\section{Endogenous variables}

Employee well-being. Previous research has suggested that when assessing well-being, it is crucial to include measures of positive as well as negative well-being (e.g., Huppert and Whittington, 2003). In our research, we measured well-being in terms of vitality to capture the positive aspects of well-being and stress to represent the negative aspects of well-being. Vitality has been defined as the sense of being alive, passionate and exited (Spreitzer and Porath, 2013). We measured it using a four-item scale extracted from Spreitzer et al., (2005), which has already been validated in previous studies (e.g., Porath et al., 2011). This scale ranged from 1 "strongly disagree" to 7 "strongly agree" and its full text is presented in Table 2 (its descriptive statistics appear in Table 3). Stress was assessed with a one-item scale (see Table 2 and Table 3) representing negative health. In our Appendix (Table B), detailed information about the validity and reliability of this measure is presented.

\section{Control variables}

When creating our survey, we included a number of demographic and contextual variables to control for potential individual and university related characteristics that could influence the relationships studied. In terms of individual characteristics, we controlled for respondents' gender (female and male), age and type of employment contract (full-time, part-time) because previous research has found these aspects influence people's perceptions of well-being (Diener et al., 1999; Gutierrez et al., 2005; Porath et al., 2011). In terms of university characteristics, we controlled for respondents' university peer group (HESA, 2012). In the 
UK, university peer groups were created as a way of classifying institutions for policy-making decisions. This classification criteria are mainly associated with their founding sources (e.g., research, teaching, special activities). Our interviews with key informants highlighted that some of these variables, including the primary source of funding (research or teaching), could significantly influence the governance mechanisms used and staff well-being. Prior to conducting our survey, we did not hypothesize about how any of these controls could affect our studied relationships.

\section{Data analysis}

Our survey data was analysed using Structural Equation Modelling (SEM). SEM is a secondgeneration multivariate method that enables the simultaneous analysis of observed and latent variables (Jöreskog, 1993). Alternative multivariate statistics methods such as regression analysis (Cohen et al., 2002) were considered. However, SEM was deemed more appropriate for this research because some of the assumptions required for regression analysis were not met; and because SEM allows the identification of potential interaction effects through multigroup analysis (Bollen, 1989; Jöreskog, 1971). Additionally, SEM permits the simultaneous evaluation of all the variables in the model rather than separately and sequentially. It also provides measurement errors without aggregating them in a residual error term (Fornell, 1984). In this research, we used MPLUS 7.11 (Muthen and Muthen, 1998-2012) and EQS 6.2 (Bentler, 1995-2008) to estimate our SEM models. All the variables in our research were assessed using a seven-item Likert scale and individual responses were associated with the university they belonged to. In our analysis, the assumptions of normality and independence were not met (Muthen and Satorra, 1995; Rivera and Satorra, 2002; Satorra and Bentler, 1994; Satorra, 1992, 2003). As a result, the general estimation method we used was MLR (maximum likelihood parameter estimates with standard errors and a chi-square test statistic that are robust to non-normality and non-independence of observation) (Muthen and Muthen, 
1998-2012). We adopted the robust Chi-square, RMSEA, SRMR and CFI indexes as indicators of model fit (Bollen, 1989; Browne and Cudeck, 1993; Hair et al., 2006; Hu and Bentler, 1999).

Before proceeding to test our hypotheses, we conducted a set of preliminary data analyses to investigate the quality of our measures and the nature of the main relationships studied. For the sake of simplicity and completeness, we have included the results of these analyses in the Appendix. For these preliminary analyses, we first calculated the descriptive statistics of the items in our measures and conducted ANOVA and Duncan tests comparing the responses of our different employment roles (Appendix-Table A). The purpose of this analyses was to examine the extent to which responses were significantly different across the employment roles studied. Next, we used confirmatory factor analysis (CFA) to examine the dimensional structure of the theoretical constructs involved in our hypotheses. We conducted CFA for our total sample and across the different employment roles sub-samples (AppendixTable B). The main relationship presented in our hypotheses suggests that the orientation of the governance practices used is related to the degree of well-being experienced by university staff. Therefore, before testing our moderating hypotheses, we analysed the extent to which this main relationship exists for the total sample including our control variables, the different employment roles and the two types of governance practices. In the Appendix, Table C shows the results of these analyses.

\section{RESULTS}

Table 3 presents the descriptive statistics and the correlation matrix of all our observed variables. Table 4 shows the results of our different structural models. As it is common in regression analysis, we present the standardized coefficients showing direct effects between 
the variables studied. Given the goodness-of-fit statistics for structural equation models, these models fit the data reasonably well as shown in Table 4.

INSERT TABLE 3 ABOUT HERE

Hypothesis 1 proposes that collegial governance practices will be positively related to the well-being of people in academic roles (without leadership responsibilities). Our model suggests (Table 4) that this is the case for the academic roles investigated. When people in academic roles experience collegial practices they also experience high levels of vitality or positive well-being $\left(\beta^{\mathrm{AC}} \text { Collegial } \rightarrow \mathrm{PW}=.53, \mathrm{p}<.01\right)^{2}$ and low levels of stress or negative wellbeing $\left(\beta_{\text {Collegial } \rightarrow \mathrm{NW}}^{\mathrm{AC}}=-.36, \mathrm{p}<.01\right)$. Thus, Hypothesis 1 is supported by our data.

Hypothesis 2 posits that control governance practices will be negatively related to the well-being of people in academic roles (referring to those academics without leadership responsibilities). Our data analysis shows (Table 4) that this relationship is partially supported. We find that when people in academic roles perceive the use of control governance practices, this perception is positively related to their stress levels. That is, those that experience high levels of control governance also experience high levels of negative well-

\footnotetext{
${ }^{2}$ We have included within parentheses the standardized coefficients $(\beta)$ resulting from our analysis and their significance level ( $\mathrm{p}$ value) to facilitate comprehension. The $\beta$ superscript indicates the employment role and its subscript indicates the path. For example, in $\left(\beta^{\mathrm{AC}}\right.$ Collegial $\left.\rightarrow \mathrm{PW}=.53, \mathrm{p}<.01\right), \mathrm{AC}$ refers to Academics without leadership responsibilities, Collegial $\rightarrow$ PW refers to the relationship between collegial governance and positive well-being (vitality), and p<.01 means that the likelihood that the phenomena tested occurred by chance alone is less than 1 percent.
} 
being $\left(\beta_{\text {Control } \rightarrow \mathrm{NW}}^{\mathrm{AC}}=.10, \mathrm{p}<.05\right)$. However, the effect of control governance practices on vitality (positive well-being) is not statistically significant $\left(\beta^{\mathrm{AC}}{ }_{\mathrm{Control} \rightarrow \mathrm{PW}}=.04, \mathrm{p}>.10\right)$. Therefore, Hypothesis 2 is partially supported.

Hypothesis 3 postulates that people in professional services roles (without leadership responsibilities) will experience positive well-being when they perceive the use of control governance practices. Our data show (Table 4) that when people in these roles experience control governance practices, they appear to feel better in terms of high vitality and low stress levels $\left(\beta^{\mathrm{PS}}{ }_{\text {Control } \rightarrow \mathrm{PW}}=.36, \mathrm{p}<.01 ; \beta^{\mathrm{PS}}{ }_{\text {Control } \rightarrow \mathrm{NW}}=-.15, \mathrm{p}<.01\right)$. These results suggest that Hypothesis 3 is supported by the data.

Hypothesis 4 highlighted that people in professional services roles (without leadership responsibilities) will perceive lower levels of well-being when they experience collegial governance practices than when they experience control practices. Our models suggest (Table 4) that perceptions of collegial practices are positively related to the well-being of people in professional services roles $\left(\beta^{\mathrm{PS}}{ }_{\text {Collegial } \rightarrow \mathrm{PW}}=.57, \mathrm{p}<.01\right.$ and $\left.\beta^{\mathrm{PS}}{ }_{\text {Collegial } \rightarrow \mathrm{NW}}=-.36, \mathrm{p}<.01\right)$. This relationship is stronger than the relationship obtained between perceptions of control governance practices and well-being. Therefore, our Hypothesis 4 is not supported by our data.

Finally, Hypotheses 5 proposes that people in leadership positions (academic and professional services) will feel good about the use of both control and collegial governance practices. For academic leaders, our models show (Table 4) that both control and collegial governance mechanisms are associated with a high sense of vitality $\left(\beta^{\mathrm{ACL}}{ }_{\text {Control } \rightarrow \mathrm{PW}}=.31\right.$, $\left.\mathrm{p}<.01 ; \beta^{\mathrm{ACL}}{ }_{\text {Collegial } \rightarrow \mathrm{PW}}=.61, \mathrm{p}<.01\right)$. This part of the hypothesis is statistically supported. However, the relationship between governance practices and stress is less clear. When academic leaders experience high collegial governance practices they also experience low 
stress levels $\left(\beta_{\text {Collegial } \rightarrow \mathrm{NW}}^{\mathrm{ACL}}=-.23, \mathrm{p}<.01\right)$ but the relationship between control governance and stress levels is not statistically significant. Further, the positive relationship between perceived collegial practices and well-being is stronger than the relationship between perceived control practices and well-being. For professional services leaders, collegial practices appear to positively affect well-being in terms of vitality $\left(\beta^{\mathrm{PML}}\right.$ Collegial $\rightarrow \mathrm{PW}=.47$, $\mathrm{p}<.01)$. The rest of relationships for this group are not statistically significant. In sum, our Hypothesis 5 is partially supported by the data.

\section{INSERT TABLE 4 ABOUT HERE}

\section{DISCUSSION}

Our analysis of the governance practices in universities reveals several interesting findings that have implications for management and higher education research. Based on previous literature (e.g., Adler and Chen, 2011; Burns and Stalker, 1961; Davis et al., 1997;

Eisenhardt, 1985; Ouchi, 1979; Rousseau, 1978), we expected universities to align their governance practices to the nature of their employees' roles to enhance their well-being. We examined these relationships by looking at the extent to which the association between university governance practices and well-being was affected by the conditions of different employment roles using agency theory (Jensen and Meckling, 1976; Eisenhardt, 1989) and stewardship theory (Davis, Schoorman and Donaldson, 1997; Hernandez, 2012) knowledge. We find that the adoption of collegial governance practices underlined by stewardship theory research is beneficial for the well-being of staff regardless of their role. Perceptions of these practices are associated with high levels of vitality and low levels of stress. Control governance practices, which correspond to the framing of agency theory, appear to be 
beneficial to the well-being of people in academic leadership positions and professional services staff. However, they appear to be detrimental for faculty without leadership responsibilities. Our findings provide empirical support to Davis' et al. (1997) research, which conceptually asserts that an alignment or misalignment between the nature of the employment relationship and the governance orientation will fulfill or fail to satisfy the motivational dispositions of staff.

We also find that the governance experiences and sense of well-being of academic leaders are more closely aligned with those of professional services leaders than with those of academics without leadership positions. As expected, despite their scholarly backgrounds, people in academic leadership roles do not seem to experience the negative effects of control governance practices that other academics feel. When academics ascend to leadership positions, it appears that the needs and expectations of the role position change their outlook and sentiment towards governance. This finding is in accordance with previous research suggesting that the constraints of a role become part of the decision-making 'program' defining the behaviour of the role-holder (Simon, 1964). Such that, the pressing needs for accountability and measurable outcomes required for external validation and legitimacy may become the focus of attention of academic leaders affecting their perceptions of governance practices and well-being.

\section{Implications for theory and future research}

Our research shows that the premises of agency theory (Jensen and Meckling, 1976; Eisenhardt, 1989) and stewardship theory (Davis, Schoorman and Donaldson, 1997; Hernandez, 2012), which are often seen as contradictory, can co-exists within single organizations, resulting in the adoption of both control and collegial governance mechanisms. Our data show that people in the various roles examined, experience both control and collegial governance practices in their universities. Further research could explore the extent 
to which these governance practices can be complementary as well as the conditions favouring or hindering that complementarity. In addition to this, further work could examine the extent to which this observed co-existence is transitory or may be permanent.

Our study offers a deeper understanding of the congruency theoretical propositions presented by Davis et al. (1997) in a non-for-profit sector. Davis and colleagues (1997) argue that specific situations produce individual preferences towards either control or collegial governance practices; and that the congruence between individual preferences and governance practices will influence individuals' well-being. In line with these ideas, our data suggests that the alignment between governance practices and employment roles in universities is associated with well-being perceptions. We have focused on employment roles as a way to designate individual preferences (Simon, 1964); however, in order to examine the extent to which different preferences and motivations influence the experience of certain governance practices, additional research could account for these individual differences.

\section{Implications for management practice}

Our findings are especially important for educational institutions and other innovationfocused organizations with a high volume of knowledge workers (i.e., low structured roles). In universities, low structured roles that include faculty research and teaching positions make up a large portion of the employment population and likewise help fulfill an overarching social, economic, environmental and cultural mission. Evidence from this study adds to the growing chorus of scholars that assert universities are mismanaging private sector-inspired reforms (Briner, 2015; Burrows, 2012; Kallio et al., 2016; McNay, 2015; Prichard and Wilmott, 1997; Toma, 2007; Willmott, 1995). Specifically, considering the importance of well-being for individual and institutional results, our data suggests that the current transition towards enhanced control governance with increasing reliance on hard performance measures and targets for academics, (e.g., Diamond, 2015) may lead to dysfunctionalities rather than 
the intended improvements (Bryson, Forth and Stokes, 2014). UK data from the Higher Education sector is already showing that the overall well-being of people in academic roles is being eroded (Kinman and Court, 2010; Kinman and Wray, 2015). As shown here, a critical explanatory factor may be the control governance practices used by universities.

Furthermore, our research shows that collegial governance practices are associated with high levels of well-being not just for people performing educational and research duties but also for people in professional services roles. Previous research has shown that increased well-being is associated with enhanced performance at work (Bryson et al., 2014) even more so for academic related undertakings (e.g., Briner and Dewberry, 2007). Our findings suggest that for university employees stewardship theory (Davis et al., 1997) may be a more effective governance philosophy than agency theory (Jensen and Meckling, 1976; Eisenhardt, 1989). Indeed, stewardship theorists often use people in academic roles as exemplars of 'stewards' (e.g., Hernandez, 2012). Our work suggests that universities could benefit from paying more attention to the conditions that people in academic roles need to produce excellent education and research. This recommendation resonates with the views of recent Nobel laureates such as Peter Higgs who has raised his concerns and argued that his discoveries would have not been possible now "as academics are expected to keep churning out papers [to meet specific research targets]" (e.g., Aitkenhead, 2013).

Some scholars argue that the move towards control governance practices appears to be associated with a particular ideology coupled with legitimacy and funding pressures (Parker and Jary, 1995; Willmott, 1995; Deem and Brehony, 2005; Deem, Hillyard and Reed, 2007; Diamond, 2015). This move seems to be ignoring or not fully considering the individual motives and working conditions required for the well-being and performance of university staff, in particular, of people in academic roles without leadership responsibilities. This move also appears to be driven by what Merton (1936, p. 901) calls the "imperious immediacy of 
interest" as university leaders become concerned with the immediate consequences of visible performance outputs (e.g., rankings, national research assessments) excluding the considerations of the future impact of increased control.

Drawing from Merton (1936), these circumstances may be conducive to unintended undesirable consequences as it could be speculated that a "self-fulfilling prophecy" may occur (Merton, 1948; Ferraro et al., 2005) with unknown results for science (Welpe et al., 2015) and the public mission of universities (Calhoum, 2011; Ortega y Gasset, 1944). Meaning that, people going into academia are often motivated to contribute to knowledge and to high quality education (Hernandez, 2012; Merton, 1996), aspects that constitute the overall mission of most public universities. However, as agency theory suggests, the use of control governance mechanisms will affect people's behaviour. Over time, the observed negative well-being effects, together with the well-known motivation and sorting effects of control mechanisms (e.g., Gomez-Mejia et al., 2010), may alter people's motivation and interests as well as attract new people with the characteristics presumed by the theory. This generally may make agency theory in this context self-fulfilling (Ferraro et al., 2009; Goshal, 2005) and the stewardship behaviours and motivation needed to significantly contribute to education and research less evident (Frey and Jegen, 2001; Frey, Homberg and Osterloh, 2013).

\section{Limitations}

Our research has several limitations that we should note. Firstly, a limitation of the study is the grouping of employment roles into a reduced set of categories. For instance, within academic roles there are significant differences between, for example, a researcher and an associate professor. Although this procedure was done for ease of analysis, and indeed the groups did show communalities, by not analysing employment roles separately, there is a possibility that some employment roles are treated differently. Future research could group academic roles into those that are more teaching or research oriented as well as those that 
come from different disciplines. Roles could also be grouped according to seniority and tasks characteristics. It could also be revealing to distinguish between the short-term or long-term nature of different employment roles. For instance, the views of academic leaders in shortterm appointments expecting to return to their normal academic role may differ from those of academic leaders who are permanently in a leadership role. The temporality of contracts (e.g., permanent vs. temporary staff) may also influence the relationships observed in this research as previous work in the sector has already shown (Fontinha, Van Laar and Easton, 2016). Then again, the current grouping of employment roles meets the purpose of our research, which was to focus on the moderating effect that two specific task characteristics (low and high structured) and two different role positions (with and without leadership responsibilities) can have on the relationship between governance practices and well-being. Further research could create alternative employment groups to gain greater granularity.

Secondly, our survey questions do not specify the organizational level at which the employee perceives collegial or control governance practices. Multilevel research would need to be conducted where responses to questions about the department, school or faculty, and university governance approaches are compared. As universities usually feature multiple layers of management, employees might experience more of a collegial practice at the department level and more of a control practice at the school/faculty level. Therefore, by not capturing this data, we are unable to identify the source of the perceived governance practice. Although, such information is important in understanding the specific origin of disagreement that leads to the perception of alignment or a misalignment of a governance practice. Because this study does not seek to reveal the origin of the disagreement, only if it was perceived at the individual level, we believe this assessment is outside the scope of this study. However, the above mentioned multilevel data collection would be useful in future research. 
Finally, in our work, we have not considered alternative theoretical perspectives that can contribute to elucidate our results ${ }^{3}$. For example, the well-being response of academic leaders could be explained by the insights of previous identity research (Winter, 2009; Lok, 2010) conducted in environments with shifting logics, such as the UK university environment (Townley, 1997). It may be the case that some faculty are more likely to embrace current leadership roles emphasising 'calculative' or 'business-like' discourses as they appeal to their individual preferences (e.g., more extrinsic drives) using them to shape their identities, which then become more similar to those of professional leaders. Others resist this 'managerial' identity and prefer to remain in their traditional academic one (Mcgivern et al., 2015). In general, we know little about the conditions under which academics take leadership roles, how the roles influence their identity, and how these aspects influence governance and wellbeing perceptions. Another relevant perspective could be the analysis of how perceptions of justice (e.g., Greenberg, 2004) from different roles may be related to the implementation of different governance practices and how these perceptions may affect people's well-being. These are areas that could benefit from further research.

\section{CONCLUSION}

This study indicates that, in the context of universities, the relationship between governance practices and well-being is affected by the role a person occupies. Despite the background and experience and individual might possess, governance practices are not always facilitated to meet the role demands of all employees in higher education institutions. We consequently show that well-being among academic faculty, who are vital to higher education institutions,

\footnotetext{
${ }^{3}$ We thank an anonymous reviewer for these insights.
} 
is influenced by a congruence or incongruence with the type of internal governance practiced. We also show that academics in leadership positions do not experience governance practices in the same way as their fellow academics. Instead, they respond to governance practices in the same manner that professional services leaders do. In conclusion, our study lends support to critics that have claimed that the introduction of "business-minded governance practices" in higher education is being mismanaged (Briner, 2015, p.1) and may have unintended undesirable consequences in the long run. 


\section{REFERENCE}

Abernethy, M. A. and A. M. Lillis (1995). 'The impact of manufacturing flexibility on management control system design', Accounting, Organizations and Society, 20, pp. 241-258.

Adler, P. S. and B. Borys (1996). 'Two types of bureaucracy: Enabling and coercive', Administrative Science Quarterly, 41, pp. 61-89.

Adler, P. S. and C. X. Chen (2011). 'Combining creativity and control: Understanding individual motivation in large-scale collaborative creativity', Accounting, Organizations and Society, 36, pp. 63-85.

Aitkenhead, D. (2013) 'Peter Higgs: I wouldn't be productive enough for today's academic system', The Guardian.

Argryis, C. (1973a). 'Organization man: Rational and self-actualizing', Public Administration Review, 33, pp. 354-357.

Argyris, C. (1973b). 'Some limits of rational man organizational theory', Public Administration Review, 33, pp. 253-267.

Armstrong, J. S. and T. S. Overton (1977). 'Estimating nonresponse bias in mail surveys', Journal of Marketing Research, 14, pp. 396-402.

Bagozzi, R. P. (2010). 'Structural equation models are modelling tools with many ambiguities: Comments acknowledging the need for caution and humility in their use', Journal of Consumer Psychology, 20, pp. 208-214.

Baiman. S. (1982). 'Agency research in managerial accounting: A survey', Journal of Accounting Literature, 1, pp. 154-213.

Barry, J., J. Chandler and H. Clark (2001). 'Between the Ivory Tower and the Academic Assembly Line', Journal of Management Studies, 38, pp. 88-101.

Bentler, P. M. (1995-2008). EQS Structural Equations Program Manual. Encino, CA: Multivariate Software Inc.

Birnbaum, R. (2004). 'The end of shared governance: Looking ahead or looking back', New Directions for Higher Education, 127, pp. 5-22.

Bolden, R., J. Gosling, A. O’Brien, K. Peters, M. Ryan and A. Haslam (2012). 'Academic leadership: Changing conceptions, identities and experiences in UK Higher Education', Leadership Foundation for Higher Education, Report, Series 3, Publication 4.

Bollen, K. A. (1989). Structural Equations with Latent Variables. New York: Wiley.

Bouillon, M. L., G. D. Ferrier, M. T. Stuebs Jr, and T. D. West (2006). 'The economic benefit of goal congruence and implications for management control systems', Journal of Accounting and Public Policy, 25, pp. 265-298.

Briner, R. (2015). 'Universities are mismanaging performance', Times Higher Education. $7^{\text {th }}$ May.

Briner, R. and Dewberry, C. (2007). 'Staff wellbeing is key to school success: A research study into the links between staff wellbeing and school performance', Retrieved from: http://www.worklifesupport.com/sites/default/files/uploadeddocuments/5902BirkbeckWBPerfSummaryFinal.pdf

Browne, M. W. and R. Cudeck (1993). 'Alternative ways of assessing model fit'. In K. A. Bollen and J. S. Long (eds), Testing Structural Equation Models, pp. 136-162. Newbury Park: Sage.

Bryson, A., Forth, J. and Stokes, L. (2014). 'Does worker wellbeing affect workplace performance?'. Department of Business Innovation \& Skills.

Bryson, C. (2004). 'What about the workers? The expansion of higher education and the transformation of academic work', Industrial Relations Journal, 35, pp. 38-57.

Buckland, R. (2009). 'Private and Public Sector Models for Strategies in Universities', British Journal of Management, 20, pp. 524-536. 
Burns, T. and G. M. Stalker (1961). The Management of Innovation. London: Tavistock.

Burrows, R. (2012) 'Living with the h-index? Metric assemblages in the contemporary academy, The Sociological Review, 60, pp. 355-372.

Caldwell, C., L. Hayes, P. Bernal and R. Karri (2008). 'Ethical stewardship - implications for leadership and trust', Journal of Business Ethics, 78, pp. 153-164.

Calhoun, C. (2011). 'The public mission of the research university'. In D. Rhoten and C. Calhoun (eds), Knowledge Matters: The Public Mission of the Research University. New York, N.Y.: Columbia University Press.

Campbell, D. J. (1988). 'Task complexity: A review and analysis', Academy of Management Review, 13, pp. 40-52.

Cardinal, L. B. (2001). 'Technological innovation in the pharmaceutical industry: The use of organizational control in managing research and development', Organization Science, 12, pp. 19-36.

Chang S., A. van Wittleloostuijn and L. Eden (2010). 'From the editors: common method variance in international business research', Journal of International Business Studies, 41, pp. 178-84.

Crilly, D., Schneider, S. C. and Zollo, M. (2008) .'Psychological antecedents to socially responsible behavior', European Management Review, 5, pp. 175-190.

Davis, J. H., F. D. Schoorman and L. Donaldson (1997). 'Toward a stewardship theory of management', Academy of Management Review, 22, pp. 20-47.

Deci, E. L. and R. M. Ryan (2010). Intrinsic Motivation and Self-determination in Human Behavior. New York: Plenum.

Decramer, A., C. Smolders, A. Vanderstraeten and J. Christiaens (2012). 'The impact of institutional pressures on employee performance management systems in Higher Education in the low countries', British Journal of Management, 23, pp. 88-103.

Deem, R. and K. Brehony (2005). 'Management as ideology: the case of 'new managerialism' in higher education'. Oxford Review of Education, 31(2), 217-235.

Deem, R., S. Hillyard and M. Reed (2007). Knowledge, Higher Education and the New Managerialism: The changing management of UK universities. Oxford: Oxford University Press.

Diamond, I. (2015). 'Efficiency, effectiveness and value for money'. Universities UK.

Diener, E., Suh, E. M., Lucas, R. E., and Smith, H. L. (1999). Subjective wellbeing: Three decades of progress. Psychological Bulletin, 125, 276-302.

Donaldson, L. and J. H. Davis (1991). 'Stewardship theory or agency theory: CEO governance and shareholder returns', Australian Journal of Management, 16, pp. 49-64.

Duckworth, K. and Cara, O. (2012). 'The Relationship between Adult Learning and Wellbeing: Evidence from the 1958 National Child Development Study', Research paper 94, UK Department for Business, Innovation \& Skills

Eisenhardt, K. M. (1985). 'Control: Organizational and economic approaches', Management Science, 31, pp. 134-149.

Eisenhardt, K. M. (1988). 'Agency-and institutional-theory explanations: The case of retail sales compensation', Academy of Management Journal, 31, pp. 488-511.

Eisenhardt, K. M. (1989). 'Agency theory: An assessment and review', Academy of Management Review, 14, pp. 57-74.

Fama, E. F. (1980). 'Agency problems and the theory of the firm', The Journal of Political Economy, 88, pp. 288-307.

Fama, E. F. and M. C. Jensen (1983). 'Separation of ownership and control', Journal of Law and Economics, 26, pp. 301-325.

Field, L. (2015). 'Appraising academic appraisal in the new public management university', Journal of Higher Education Policy and Management, 37, pp. 172-189. 
Franco-Santos, M., P. Rivera and M. Bourne (2014). 'Performance Management in UK Higher Education Institutions: The Need for a Hybrid Approach', Leadership Foundation for Higher Education.

Frey, B. S., F. Homberg and M. Osterloh (2013). 'Organizational control systems and payfor-performance in the public service', Organization Studies, 34, pp. 950-972.

Gomez-Mejia, L. R. and D. B. Balkin (1992). 'Determinants of faculty pay: An agency theory perspective', Academy of Management Journal, 35, pp. 921-955.

Gomez-Mejia, L., Berrone, P. and Franco-Santos, M. (2010). 'Compensation and organizational performance: Theory, research and practice'. New York: M.E. Sharpe Inc.

Graham, J. W. and D. W. Organ (1993). 'Commitment and the covenantal organization', Journal of Managerial Issues, 5, pp. 483-502.

Greenberg, J. (2004) Stress fairness to fare no stress: Managing workplace stress by promoting organizational justice, Organizational Dynamics, 33(4), pp. 352-365.

Gutierrez, J. L. G., Jimenez, B. M., Hernandez, E. G., and Puente, C. P. (2005). Personality and subjective wellbeing: Big five correlates and demographic variables. Personality and Individual Differences, 38, 1561-1569.

Hair, J. F., W. C. Black, B. J. Babin, R. E. Anderson and R. L. Tatham (2006). Multivariate Data Analysis (6th Ed.). Upper Saddle River, New Jersey: Prentice Hall.

Hambrick, D., Nadler, D. and Tushman, M. L. (1998). 'Navigating Change: How CEO's, Top Teams and Boards Steer Transformation'. Boston, MA: Harvard Business School Press.

Heath, J. (2009). 'The uses and abuses of agency theory', Business Ethics Quarterly, 19, pp. 497-528.

Hernandez, M. (2012). 'Toward an understanding of the psychology of stewardship', Academy of Management Review, 37, pp. 172-193.

HESA (2012). 'Published statistics of UK Higher Education Institutions'. Available at: https://www.hesa.ac.uk (accessed November 2012).

Hess, A. M. and F. T. Rothaermel (2011). 'When are assets complementary? Star scientists, strategic alliances, and innovation in the pharmaceutical industry', Strategic Management Journal, 32, pp. 895-909.

Hoskisson, R. E. and M. A. Hitt (1988). 'Strategic control systems and relative R and D investment in large multiproduct firms', Strategic Management Journal, 9, pp. 605-62.

Hu, L. and P. M. Bentler (1999). 'Cut-off criteria for fit indexes in covariance structure analysis: Conventional criteria versus new alternatives', Structural Equation Modelling, 6, pp. 1-55.

Huhtala, H. and M. Parzefall (2007). 'A review of employee well-being and innovativeness: An opportunity for mutual benefit', Creativity and Innovation Management 16(3), pp. 299-306

Huppert, F. A. and J. E. Whittington (2003). 'Evidence for the independence of positive and negative wellbeing: Implications for quality of life', British Journal of Health Psychology, 8, pp. 107-122.

Jensen, M. C. and W. H. Meckling (1976). 'Theory of the firm: Managerial behaviour, agency costs and ownership structure', Journal of Financial Economics, 3, pp. 305-360.

Jöreskog, K. G. (1971). 'Simultaneous factor analysis in several populations', Psychometrika, 36, pp. 409-426.

Jöreskog, K. G. (1993). 'Testing structural equation models'. In K. A. Bollen and J. S. Long (eds), Testing Structural Equation Models, pp. 294-316. Newbury Park, CA: Sage.

Kallio, K-M., T. J. Kallio, J. Tienari and T. Hyvonen (2016) 'Ethos at stake: Performance management and academic work in universities', Human Relations, 69, pp. 685-709 
Kallio, K.-M. and T. J. Kallio (2014). 'Management-by-results and performance measurement in universities - implications for work motivation', Studies in Higher Education, 39, pp. 574-589.

Kezar, A. J. and P. D. Eckel (2004). 'Meeting today's governance challenges: A synthesis of the literature and examination of a future agenda for scholarship', The Journal of Higher Education, 75, pp. 371-399.

Kinman, G. and Court, S. (2010). 'Psychosocial Hazards in UK Universities: Adopting a Risk Assessment Approach', Higher Education Quarterly, 64, pp. 413-428.

Kinman, G. and Wray, S. (2015). 'Taking its toll: rising stress levels in further education UCU Stress Survey 2014'. University College Union Report.

Levinthal, D. (1988). 'A survey of agency models of organizations', Journal of Economic Behavior and Organization, 9, pp. 153-185.

Makri, M., P. J. Lane and L. Gomez-Mejia (2006). 'CEO incentives, innovation, and performance in technology-intensive firms: A reconciliation of outcome and behaviourbased incentive schemes', Strategic Management Journal, 27, pp. 1057-1080.

March, J. and H. Simon (1958). Organizations. Wiley: New York.

Martin, B. (2012). 'Are universities and university research under threat? Towards an evolutionary model of university speciation', Cambridge Journal of Economics, 36, pp. 543-565.

McLendon, M. K., J. C. Hearn and R. Deaton (2006). 'Called to account: Analyzing the origins and spread of state performance-accountability policies for higher education', Educational Evaluation and Policy Analysis, 28, pp. 1-24.

McNay, I. (2015), 'Debate: Does research quality assessment increase output and give value for money? Public Money and Management, 35, pp. 67-68.

Merton, R. K. (1996). 'On social structure and science'. Chicago: University of Chicago Press.

Miller, J. S., R. M. Wiseman and L. R. Gomez-Mejia (2002). 'The fit between CEO compensation design and firm risk', Academy of Management Journal, 45, pp. 745756.

Milliken, J. and G. Colohan (2004). 'Quality or control? Management in higher education', Journal of Higher Education Policy and Management, 26, pp. 381-391.

Morrish, L. and H. Sauntson (2016). 'Performance management and the stifling of academic freedom and knowledge production', Journal of Historical Sociology, 29, pp. 42-64.

Muthen B. O. and A. Satorra (1995). 'Complex sample data in structural equation modeling', Sociological Methodology, 25, pp. 267-316.

Muthén, L. K. and B. O. Muthén (1998-2012). Mplus User's Guide. Fifth Edition. Los Angeles, CA: Muthén and Muthén.

Neumark, V. (2014). 'Teachers' wellbeing: under scrutiny and underappreciated', The Guardian.

Ortega y Gasset, J. (1944). Mission of the University (H.L. Nostrand, Ed and Trans.), Princeton, N.J.: Princeton University Press.

Ouchi, W. G. (1977). 'The relationship between organizational structure and organizational control', Administrative Science Quarterly, 22, pp. 95-113.

Ouchi, W. G. (1979). 'A conceptual framework for the design of organizational control mechanisms', Management Science, 25, pp. 833-848.

Parker, M. and Jary, D. (1995). 'The McUniversity: Organization, Management and Academic Subjectivity', Organization, 2, pp. 319-338.

Perrow, C. (1961). 'The Analysis of Goals in Complex Organizations', American Sociological Review, 26, pp. 854-866. 
Podsakoff, P., S. MacKenzie and N. Podsakoff (2012). 'Sources of method bias in social science research and recommendations on how to control it', Annual Reviews of Psychology, 63, pp. 539-569.

Pollitt, C. (1987). 'The politics of performance assessment: Lessons for higher education?', Studies in Higher Education, 12, pp. 87-98.

Porath, C., Spreitzer,G., Gibson, G. and Garnett, F. (2011). 'Thriving at work: Toward its measurement, construct validation, and theoretical refinement', Journal of Organization Behavior, 33, pp. 250-271.

Prichard, C. and Willmott, H. (1997) 'Just how managed is the McUniversity?' Organization Studies, 18, pp. 287-316.

Rhoades, G. (2005). 'Capitalism, academic style, and shared governance', Academe, 91, pp. $38-42$.

Rivera, P. and A. Satorra (2002). 'Analysing group differences: a comparison of SEM approaches'. In G. Marcoulides and I. Moustaki (eds.), Latent Variable and Latent Structure Models, pp. 86-104. Mahwah, USA: Lawrence Erlbaum Associates, Inc.

Rousseau, D. M. (1978). 'Characteristics of departments, positions and individuals: Contexts for attitudes and behaviour', Administrative Science Quarterly, 23, pp. 521-540.

Satorra, A. (1992). 'Asymptotic robust inferences in the analysis of mean and covariance structures', Sociological Methodology, 22, pp. 249-278.

Satorra, A. (2003). 'Power of chi-square goodness-of-fit test in structural equation models: the case of non-normal data'. In H. Yanai, A. Okada, K. Shigemasu, Y. Kano and J. J. Meulman (eds), New Developments of Psychometrics, pp. 57-68. Tokyo: Springer Verlag.

Satorra, A. and P. M. Bentler (1994). 'Corrections to test statistics and Standard errors in covariance structure analysis'. In A. von Eye and C. C. Clogg (eds), Latent variables analysis: Applications for developmental research, pp. 399-419. Thousand Oaks, CA: Sage.

Schimank, U. (2005). 'New public management' and the academic profession: Reflections on the German situation', Minerva, 43, pp. 361-376.

Schmidtlein, F. A. and R. O. Berdahl (2005). 'Autonomy and accountability: Who controls academe? American higher education in the twenty-first century', Social, Political, and Economic Challenges, 2, pp. 71-90.

Segal, L. and M. Lehrer (2012). 'The institutionalization of stewardship: theory, propositions, and insights from change in the Edmonton public schools', Organization Studies, 33, pp. 169-201.

Simon, H. (1964). 'On the concept of organizational goal', Administrative Science Quarterly, 9, pp. 1-22.

Shore, C. (2008), 'Audit culture and illiberal governance', Anthropological Theory, 8, pp. 278-298.

Sporn, B. (1999). 'Adaptive University Structures: An Analysis of Adaptation to Socioeconomic Environments of US and European Universities', Higher Education Policy Series 54. Taylor and Francis, Philadelphia.

Spreitzer, G. and C. Porath (2013). 'Self-determination as nutriment for thriving: building an integrative model of human growth at work'. In M. Gagne (2013) Oxford Handbook of Work Engagement, Motivation, and Self-Determination Theory. New York, Oxford University Press.

Spreitzer, G., K. Sutcliffe, J. Dutton, S. Sonenshein and A. Grant (2005). 'A socially embedded model of thriving at work', Organization Science, 16, pp. 537-549.

Ter Bogt, H. J. and R. W. Scapens (2012). 'Performance management in universities: Effects of the transition to more quantitative measurement systems', European Accounting Review, 21, pp. 451-497. 
Toma, J. D. (2007). 'Expanding peripheral activities, increasing accountability demands and reconsidering governance in US higher education', Higher Education Research and Development, 26, pp. 57-72.

Tosi, H. L., A. L. Brownlee, P. Silva and J. P. Katz (2003). 'An empirical exploration of decision making under agency controls and stewardship structure', Journal of Management Studies, 40, pp. 2053-2071.

Townley, B. (1997). 'The institutional logic of performance appraisal', Organization Studies, 18, pp. 261-285.

Tuomela, T.-S. (2005). 'The interplay of different levers of control: A case study of introducing a new performance measurement system', Management Accounting Research, 16, pp. 293-320.

Turner, K. L. and M. V. Makhija (2006). 'The role of organizational controls in managing knowledge', Academy of Management Review, 31, pp. 197-217.

USA Today (2013). 'UT-Austin at center of fight over the purpose of college'. Available at: www.usatoday.com_(accessed 2nd February 2015).

Veldhoven, M.V. and Peccei, R. (2015). 'Well-Being and Performance at Work: The Role of Context', Psychology Press, New York.

Waitere, H. J., J. Wright, M. Tremaine, S. Brown and C. J. Pausé (2011). 'Choosing whether to resist or reinforce the new managerialism: The impact of performance-based research funding on academic identity', Higher Education Research and Development, 30, pp. 205-217.

Welpe, I., J. Wollersheim, S. Ringelhan and M. Osterloh (2015). Incentives and performance: Governance or research organizations. Cham: Springer International Publishing.

Whitchurch, C. (2013). Reconstructing Identities in Higher Education: The Rise of Third Space Professionals. New York: Routledge.

Willmott, H. (1995) 'Managing the academics: Commodification and control in the development of university education in the UK'. Human Relations 48, pp. 993-1027.

Yukl, G. (2008). 'How leaders influence organizational effectiveness', Leadership Quarterly, 19 , pp. 708-722.

Zusman, A. (2005). 'Challenges facing higher education in the twenty-first century. American higher education in the twenty-first century', Social, Political, and Economic Challenges, 2, pp. 115-160. 
FIGURE 1: Employment roles

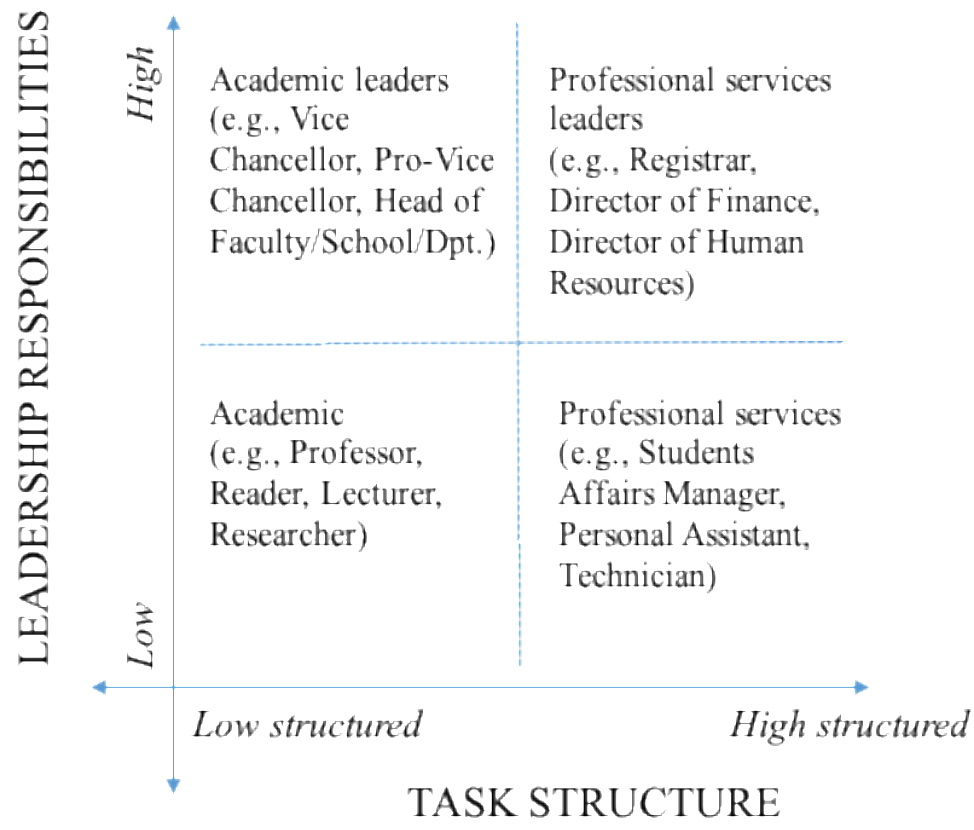


TABLE 1: Sample description

\begin{tabular}{|c|c|c|}
\hline Variables & $\mathbf{N}$ & $\%$ \\
\hline \multicolumn{3}{|l|}{ Respondents' role } \\
\hline $\begin{array}{l}\text { Academic } \\
\text { (e.g., Professor, Reader, Senior Lecturer, Senior Researcher, Lecturer, Researcher) }\end{array}$ & 573 & 58.8 \\
\hline $\begin{array}{l}\text { Academic leader } \\
\quad \text { (e.g., Vice Chancellor, Pro-Vice Chancellor, Head of Faculty/School/Department) }\end{array}$ & 136 & 13.9 \\
\hline $\begin{array}{l}\text { Professionals services manager and Support } \\
\text { (e.g., Head of Training and Development, Head of Student Affairs, Head of } \\
\text { Planning and Policy, Personal Assistant, Secretary, Administrative, Technician, } \\
\text { Officer) }\end{array}$ & 202 & 20.7 \\
\hline $\begin{array}{l}\text { Professional services leader } \\
\quad \text { (e.g., Registrar, Director of Finance, Director of Human Resources) }\end{array}$ & 64 & 6.6 \\
\hline \multicolumn{3}{|l|}{ Respondents' gender } \\
\hline Male & 462 & 47.4 \\
\hline Female & 513 & 52.6 \\
\hline \multicolumn{3}{|l|}{ Respondents' age } \\
\hline Less than 35 & 92 & 9.3 \\
\hline $36-45$ & 209 & 21.5 \\
\hline $46-55$ & 390 & 40.0 \\
\hline $56-65$ & 267 & 27.4 \\
\hline More than 66 & 17 & 1.7 \\
\hline \multicolumn{3}{|l|}{ Respondents' employment contract } \\
\hline Full time & 853 & 87.5 \\
\hline Part time & 122 & 12.5 \\
\hline \multicolumn{3}{|l|}{ Respondents' university peer group } \\
\hline$P G \_A:$ Russell group (excluding LSE) & 210 & 21.5 \\
\hline$P G \_B:$ All other institutions with research income of $22 \%$ or more of total & 168 & 17.2 \\
\hline$P G \_C:$ Institutions with research income $8-21 \%$ of total & 86 & 8.8 \\
\hline$P G \_D$ : Institutions with research income $5-8 \%$ of total and total income $>£ 120 m$ & 268 & 27.5 \\
\hline$P G \_E:$ Teaching institutions with a turnover of $£ 40 m$ and $£ 119 m$ & 103 & 10.6 \\
\hline$P G \_F:$ Smaller teaching institutions & 114 & 11.7 \\
\hline$P G_{-} G:$ Specialist music/arts teaching institutions & 26 & 2.7 \\
\hline
\end{tabular}


TABLE 2: Constructs and measurement scales

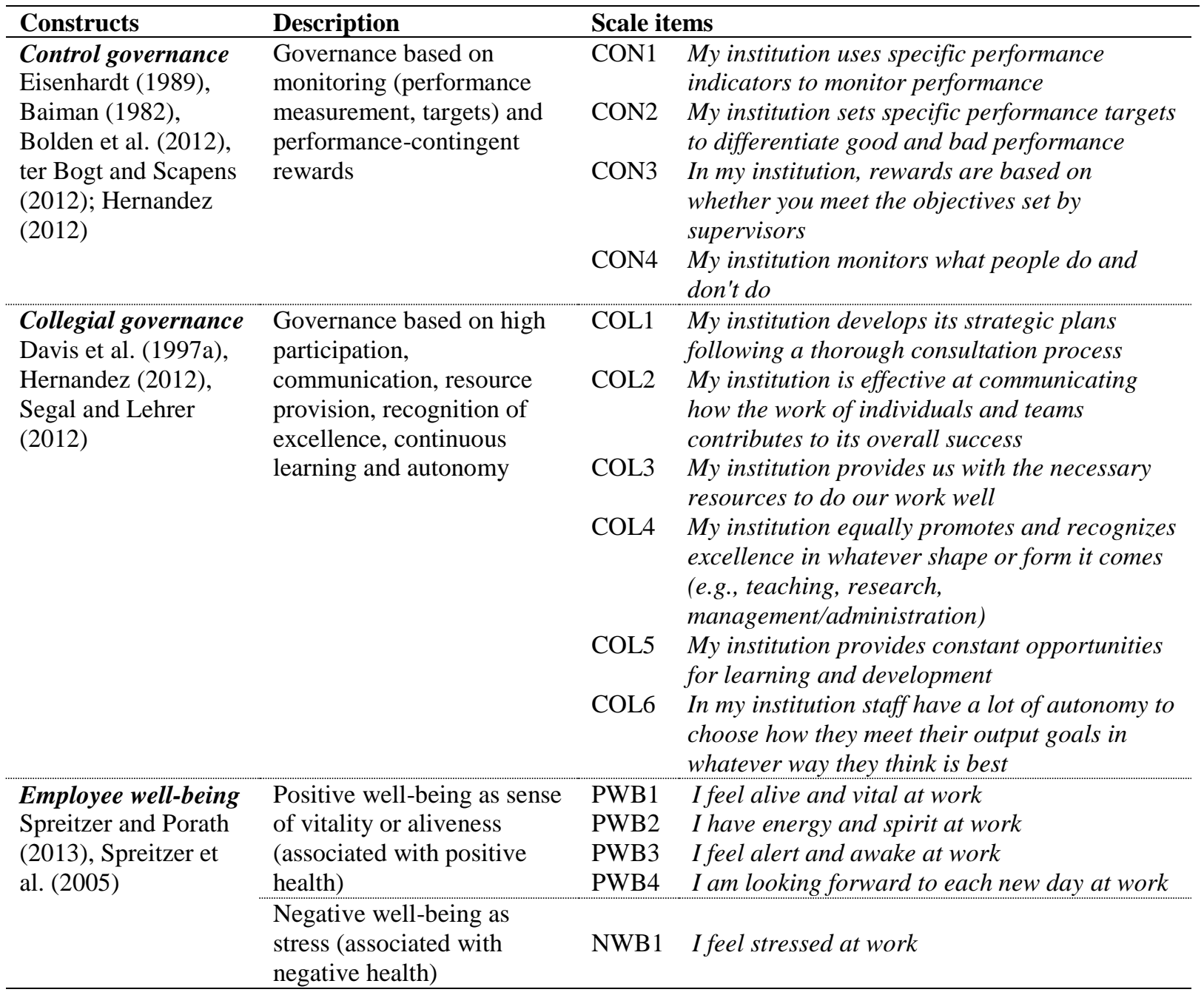


TABLE 3: Descriptive statistics and correlation matrix

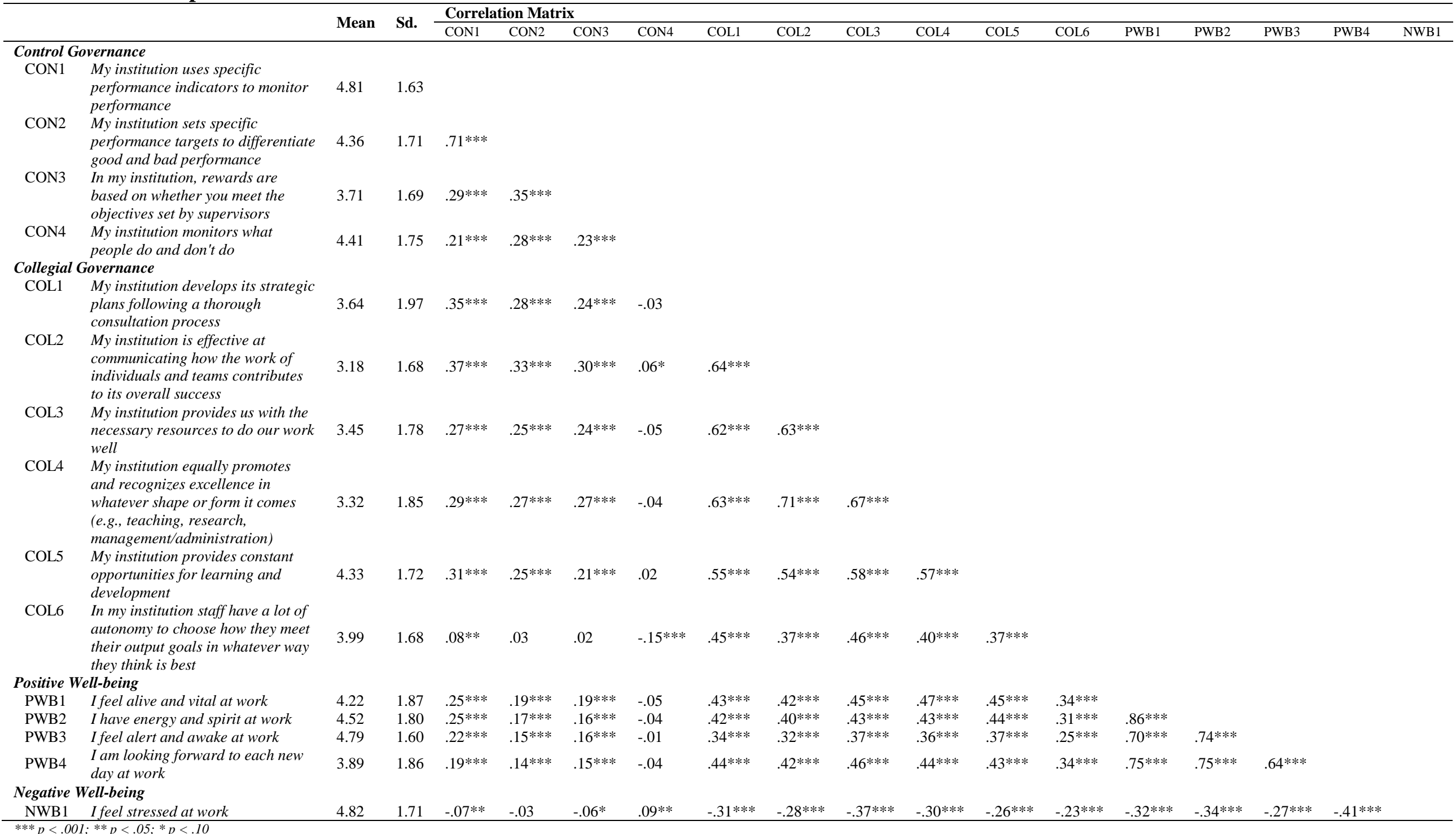


TABLE 4: Governance practices and well-being across groups of employment roles

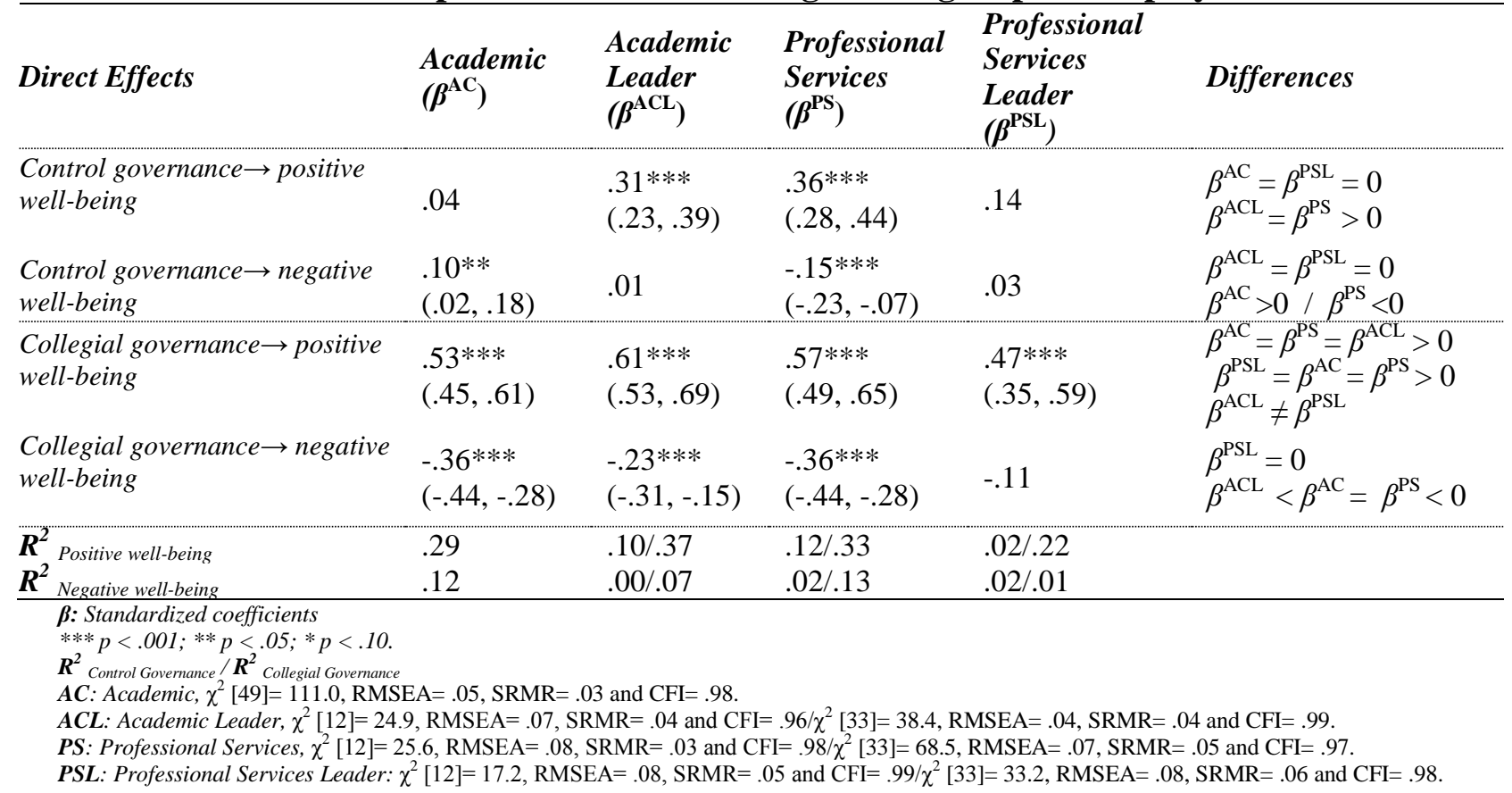




\section{APPENDIX}

In this appendix we present the actions we took to prevent potential biases and the preliminary analyses conducted before testing our hypotheses. Our preliminary analyses include our descriptive statistics together with our measurement and structural models.

\section{Controlling for biases}

During the research design phase, we considered ex-ante remedies to prevent potential bias in our data analysis (Chang et al., 2010; Podsakoff, et al., 2012). Firstly, we conducted a pilot survey to validate and test our measures in one UK university. After receiving verbal and written feedback from respondents, we reviewed and polished some of the items in our measures. Secondly, we focused our survey on staff working in UK universities and we gathered our data using an on-line survey. We gave our survey participants the opportunity to respond anonymously to the questionnaire. We also reassured them about the confidentiality of the data. Participants were made aware of the fact that the survey data was for research purposes only rather than commercial or political. These ex-ante remedies are needed to reduce problems in the comprehension phase of the survey process; however, they are not sufficient to enable us to completely avoid potential selection and common method biases (Chang et al., 2010). Hence, we applied ex-post statistical control strategies to test for selection and common method biases. Regarding selection bias, following Armstrong and Overton (1977) we compared early and late respondents of the questionnaire in the observed variables. The statistical tests for differences between means were not significant at 0.05 , which suggests that selection bias was not a serious problem in this research. To control for common method variance (CMV), we used Harman's single-factor test. All the observed variables were subjected to principal components analysis, and the first un-rotated component explains less than 40 percent of the variance. Furthermore, we estimated a single-factor confirmatory model. This model had a bad fit $(\chi 2[90]=2776.72, \mathrm{RMSEA}=.18, \mathrm{SRMR}=.12$ and $\mathrm{CFI}=.58)$. Consequently, no single factor can explain the data structure. Based on the results of the Harman single-factor test, the goodness of fit of the single-factor confirmatory model and the proposed theoretical model we do not expect common method variance to be a serious problem in our research.

\section{Descriptive statistics}

Table A presents the descriptive statistics of the observed variables of our constructs across the different respondents' roles, using the analysis of variance (ANOVA) and Duncan's multiple-range test. The purpose of our ANOVA and Duncan's test was to examine the extent to which responses were significantly different across our different groups of employment. We find that within the control governance construct the use of specific performance metrics and monitoring was consistently rated high across all respondent groups. It must be noted that people in leadership roles indicated slightly higher levels of the use of performance metrics than the academic and professional services roles. Within the collegial governance construct respondents consistently rated that their institution provided lowers levels of communication, resource provision, developmental support, and recognition of excellence. Autonomy (COL6) was the highest rated item of the collegial governance measure and it rated fairly high across the different groups. Moreover, people in academic roles perceived slightly lower levels of collegial governance compared with people in professional services roles and leadership roles. Positive well-being was shown to be similar between people in academic and professional services roles and slightly higher among people in leadership roles. However, negative well-being was shown to be notably higher among people in academic roles as compared with the well-being experienced by people in professional services and leadership roles. This data provides preliminary evidence supporting the moderating effect that employment role has on the relationship between governance practices and well-being. People in different roles perceive the existence of control and collegial governance practices. However, they perceive these practices in different levels with distinctive consequences for their well-being. 


\section{Measurement model}

We used confirmatory factor analysis (CFA) to examine the dimensional structure of the theoretical constructs involved in our hypotheses. We conducted CFA for our total sample and across the different groups of employment roles. In order to assess our measurement model, we followed the approach suggested by Bagozzi (2010). We analyzed the reliability of our constructs, together with their convergent and discriminant validity. The reliability of the observed variables was evaluated with the standardized factor loadings of the indicators for each construct and their reliability coefficients. We used three coefficients to measure the precision for each of our measures: the cronbach's alpha coefficient $(\alpha)$, the composite reliability coefficient $(\mathrm{CRC})$, and the average variance extracted (AVE). The recommended values for $\alpha$ and CRC are above .70 and for AVE is above .50 (Bagozzi, 2010). With a given model of measurement, the parameters of interest for the evaluation of discriminant validity of the constructs are the AVE coefficients and the estimation of the squared correlations among these constructs. These parameters are analyzed to determine whether 1 lies inside all the confidence intervals around the correlation estimate between any two factors. Furthermore, from the size of the correlations between the factors of the first order, we evaluated if there were a second-order factor involved in our data (Bagozzi, 2010).

In order to evaluate the dimensional structure of our constructs, we estimated a first-order fourfactor model across the total sample of responses and each of our employment roles (see Table B: Complete Measurement Model). In the total sample, given the goodness-of-fit statistics of this model, we could not refuse it (Total Sample: $\chi 2[85]=349.3, \mathrm{RMSEA}=.06, \mathrm{SRMR}=.06, \mathrm{CFI}=$ .96); however, the data showed that two items from the control governance scale (CON3 and CON4) and one from the collegial governance scale (COL6) present reliability issues. For conducting our multi-group confirmatory factor analysis, we estimate a first order four-factor model across the four groups of employment roles. The goodness-of-fit statistics show that these models fit the data reasonably well (Academic: $\chi 2[85]=219.5$, RMSEA $=.05, \mathrm{SRMR}=.06, \mathrm{CFI}=.96$; Academic Leader: $\chi 2$ [85]= 127,9, RMSEA $=.06, \mathrm{SRMR}=.07, \mathrm{CFI}=.95$; Professional Services: $\chi 2$ $[85]=194.8, \mathrm{RMSEA}=.08, \mathrm{SRMR}=.06, \mathrm{CFI}=.93$; and Professional Services Leader: $\chi 2$ [85]= $140.3, \mathrm{RMSEA}=.10, \mathrm{SRMR}=.09, \mathrm{CFI}=.87$ ). The results of $\mathrm{CON} 3$ and $\mathrm{CON} 4$ were not surprising taking into consideration the context of our research and the fact that there is great variability in the extent to which UK universities have implemented incentive rewards and individual performance monitoring (Diamond, 2015). Because of these results, we decided to remove these items and obtain a better representation of reality in terms of reliability and convergent validity, without affecting the scales' predictive validity.

After refining our measurement scales, we conducted another first-order four-factor model (see Table B: Reduced Measurement Model). This new measurement model fits the data reasonable well (Total Sample: $\chi 2$ [49]= 164.4, RMSEA= .05, SRMR= .03, CFI= .98; Academic: $\chi 2$ [49]= 111.0, $\mathrm{RMSEA}=.05, \mathrm{SRMR}=.03, \mathrm{CFI}=.98$; Academic Leader: $\chi 2$ [49]= 56.7, RMSEA= .03, SRMR= $.04, \mathrm{CFI}=.99$; Professional Services: $\chi 2$ [49]= 117.9, RMSEA $=.08, \mathrm{SRMR}=.05, \mathrm{CFI}=.95$ and Professional Services Leader: $\chi 2$ [49]= 52.7, RMSEA $=.03, \mathrm{SRMR}=.07, \mathrm{CFI}=.98$ ). Table B also shows that the standardized parameter estimates and the reliability coefficients obtained are evidence of the reliability and convergent validity of our factors. With regard to evaluating discriminant validity, the AVEs are above the squared correlation among the latent variables and furthermore 1 is not within the confidence intervals around the correlation estimate between the factors.

It is important to note that we detected that in the Academic Leader, Professional Services and Professional Services Leader groups the correlations among the exogenous latent variables (control and collegial governance $)$ are above $.70\left(\phi^{\mathrm{ACL}}=.73 ; \phi^{\mathrm{PSMS}}=.71\right.$; and $\left.\phi^{\mathrm{PSL}}=.70\right)$, while in the total sample and in the Academic group these correlations are below $.45\left(\phi^{\mathrm{TS}}=.44\right.$ and $\left.\phi^{\mathrm{AC}}=.22\right)$. Such 
high correlations reveal the potential existence of a second order factor (Governance Practices) with two first-order latent variables (control and collegial governance). Thus, we estimated a new model, that is a second-order confirmatory factor model, with the equivalent latent variables

$\left(\lambda_{\text {ControlGO }}=\lambda_{\text {CollegialGO }}\right)$. This model is equivalent to the first-order four-factor model; it has the same goodness of fit. The parameter estimated in the three groups offers high convergent validity and reliability indices $\left(\lambda>.70, \mathrm{R}^{2}>.50, \alpha>.70, \mathrm{CRC}>.70\right.$ and $\left.\mathrm{AVE}>.50\right)$. It can therefore be concluded that there is a higher-order construct called 'Governance practices' with two first-order dimensions (control and collegial governance practices) for people in academic leader, professional services and professional services leader roles. Again, the results of our data analyses so far, support the existence of a moderating effect of employment roles as suggested in our hypotheses.

\section{Structural Models}

Before testing our hypotheses, we analyzed the extent to which our endogenous variable well-being was directly being affected by our control variables, the different employment roles and the two sets of governance practices. We conduct these analyses with three different structural models. Table C presents the goodness-of-fit indexes and the main parameter estimates of these three structural models. Our first estimated model (Model_1), considers the relationship between well-being (positive and negative) and our control variables: Respondents' gender, respondents' age, respondents' employment contract and respondents' university peer group. This model shows a reasonable fit (Model_l: $\chi^{2}[32]=97.50$, RMSEA=.05, SRMR=.02 and CFI=.98), but the percentages of explained variance are very small in both endogenous variables ( $2 \%$ for vitality or positive well-being and $2 \%$ for stress or negative well-being). Regarding positive well-being, only respondents' age appears to have a positive and significant effect $\left(\beta_{\mathrm{AGE} \rightarrow \mathrm{PW}}=.09 ; \mathrm{p}<.05\right)$. This result suggests that older individuals have higher levels of well-being. Regarding negative well-being, respondents' gender has a positive and significant effect $\left(\beta_{\mathrm{FEMALE} \rightarrow \mathrm{NW}}=.08 ; \mathrm{p}<.05\right)$, which suggests that women experience higher levels of stress than men.

In our second structural model (Model_2), we add to the original model the different employment roles as exogenous variables. We establish 'Academic roles' as our base group. This model shows a reasonable fit as presented in Table C (Model_2: $\chi^{2}[41]=110.74$, RMSEA $=.04$, SRMR=.01 and $\mathrm{CFI}=.98$ ). The percentages of explained variance of positive well-being and negative well-being are $15 \%$ and $9 \%$, respectively. The increments in $\mathrm{R}^{2}$ of Model_2 in relation to Model_1 are significant $\left(\Delta \mathrm{R}_{\mathrm{PW}}^{2}=.13\right.$ and $\left.\Delta \mathrm{R}_{\mathrm{NW}}^{2}=.07 \mathrm{p}<.01\right)$. None of the control variables in Model_2 appear to influence positive well-being. In terms of negative well-being, respondent's gender shows a positive and significant effect $\left(\beta_{\mathrm{FEMALE} \rightarrow \mathrm{NW}}=.09 ; \mathrm{p}<.05\right)$. In this model, employment role also has an effect on well-being. In particular, people in leadership roles show greater positive well-being than people in academic roles $\left(\beta_{\mathrm{ACL} \rightarrow \mathrm{PW}}=.32 ; \mathrm{p}<.01 ; \beta_{\mathrm{PSL} \rightarrow \mathrm{PW}}=.24 ; \mathrm{p}<.01\right)$. Regarding negative well-being, people in academic roles are the ones that more stress experience $\left(\beta_{\mathrm{ACL} \rightarrow \mathrm{NW}}=-.17, \beta_{\mathrm{PS} \rightarrow \mathrm{NW}}=-.17\right.$ and $\left.\beta_{\mathrm{PSL} \rightarrow \mathrm{NW}}=-.19 ; \mathrm{p}<.01\right)$.

In our third structural model (Model_3), we add to the variables in Model_2 control and collegial governance practices. As presented in Table $\mathrm{C}$, our analysis shows that the model fits the data reasonably well (Model_3: $\chi^{2}[145]=355.54$, RMSEA=.04, SRMR=.02 and CFI=.97). The increments in $\mathrm{R}^{2}$ of Model_3 in relation to Model_2 are also significant $\left(\Delta \mathrm{R}_{\mathrm{PW}}^{2}=.26\right.$ and $\Delta \mathrm{R}^{2} \mathrm{NW}$ $=.10 \mathrm{p}<.01)$. Like in Model_2, none of the control variables have a significant effect on positive well-being. However, respondent's gender, as it occurred in Model_2, does have a positive and significant effect on negative well-being $\left(\beta_{\mathrm{FEMALE} \rightarrow \mathrm{NW}}=.07 ; \mathrm{p}<.05\right)$. The coefficients of our employment role variables decrease when the governance practices variables are introduced, but they do not change their sign or significance $\left(\beta_{\mathrm{ACL} \rightarrow \mathrm{PW}}=.10 ; \mathrm{p}<.01, \beta_{\mathrm{PSL} \rightarrow \mathrm{PW}}=.06 ; \mathrm{p}<.05, \beta_{\mathrm{ACL} \rightarrow \mathrm{NW}}=-\right.$ $.05 ; \mathrm{p}<.10, \beta_{\mathrm{PS} \rightarrow \mathrm{NW}}=-.07 ; \mathrm{p}<.05$ and $\left.\beta_{\mathrm{PSL} \rightarrow \mathrm{NW}}=-.08 ; \mathrm{p}<.05\right)$. In parallel, the results of Model_3 show that the use of control governance practices does not seem to relate to people's sense of vitality or 
positive well-being $\left(\beta_{\text {Control } \rightarrow \mathrm{PW}}=-.01 ; \mathrm{p}>.10\right)$, but it does relate to the level of stress or negative well-being they experience $\left(\beta_{\text {Control } \rightarrow \mathrm{NW}}=.10 ; \mathrm{p}<.01\right)$. On the other hand, when people perceive the use of collegial governance, they also experience high levels of vitality $\left(\beta_{\text {Collegial } \rightarrow P W}=.58 ; \mathrm{p}<.01\right)$ and low levels of stress $\left(\beta_{\text {Collegial } \rightarrow \mathrm{NW}}=-.39 ; \mathrm{p}<.01\right)$. 
TABLE A: Descriptive statistics across groups of employment roles

\begin{tabular}{|c|c|c|c|c|c|c|c|}
\hline & & Academic & Academic Leader & $\begin{array}{l}\text { Professionals } \\
\text { Services }\end{array}$ & $\begin{array}{l}\text { Professional } \\
\text { Services Leader }\end{array}$ & \multirow{2}{*}{ ANOVA } & \multirow{2}{*}{$\begin{array}{l}\text { Duncan-Test } \\
\text { Differences }\end{array}$} \\
\hline & & $\begin{array}{l}\text { Mean } \\
\bar{X}^{A C}\end{array}$ & $\frac{\text { Mean }}{\bar{X}^{A C L}}$ & $\frac{\text { Mean }}{\mathrm{X}}$ & $\frac{\text { Mean }}{\mathrm{X}}$ & & \\
\hline \multicolumn{8}{|c|}{ Control Governance } \\
\hline CON1 & $\begin{array}{l}\text { My institution uses specific performance indicators to monitor } \\
\text { performance }\end{array}$ & 4.64 & 5.45 & 4.68 & 5.42 & $13.06^{* * *}$ & $\mathrm{AC}=\mathrm{PSMS}<\mathrm{PL}=\mathrm{ACL}$ \\
\hline $\mathrm{CON} 2$ & $\begin{array}{l}\text { My institution sets specific performance targets to differentiate good and } \\
\text { bad performance }\end{array}$ & 4.25 & 4.79 & 4.17 & 5.06 & $8.23^{* * *}$ & $\mathrm{PSMS}=\mathrm{AC}<\mathrm{ACL}=\mathrm{PSL}$ \\
\hline CON3 & $\begin{array}{l}\text { In my institution, rewards are based on whether you meet the objectives } \\
\text { set by supervisors }\end{array}$ & 3.56 & 4.27 & 3.54 & 4.33 & $10.47 * * *$ & $\mathrm{PSMS}=\mathrm{AC}<\mathrm{ACL}=\mathrm{PSL}$ \\
\hline CON4 & My institution monitors what people do and don't do & 4.47 & 4.57 & 4.08 & 4.57 & $3.18^{* *}$ & $\mathrm{PSMS}=\mathrm{AC} A C=\mathrm{ACL}=\mathrm{PSL}$ \\
\hline \multicolumn{8}{|c|}{ Collegial Governance } \\
\hline COL1 & $\begin{array}{l}\text { My institution develops its strategic plans following a thorough } \\
\text { consultation process }\end{array}$ & 2.93 & 4.93 & 4.23 & 5.34 & $83.28 * * *$ & $\mathrm{AC}<\mathrm{PSMS}<\mathrm{ACL}=\mathrm{PSL}$ \\
\hline COL2 & $\begin{array}{l}\text { My institution is effective at communicating how the work of individuals } \\
\text { and teams contributes to its overall success }\end{array}$ & 2.73 & 4.11 & 3.49 & 4.22 & $43.05 * * *$ & $\mathrm{AC}<\mathrm{PSMS}<\mathrm{ACL}=\mathrm{PSL}$ \\
\hline COL3 & $\begin{array}{l}\text { My institution provides us with the necessary resources to do our work } \\
\text { well }\end{array}$ & 2.95 & 4.51 & 3.75 & 4.75 & $51.03 * * *$ & $\mathrm{AC}<\mathrm{PSMS}<\mathrm{ACL}=\mathrm{PSL}$ \\
\hline COL4 & $\begin{array}{l}\text { My institution equally promotes and recognizes excellence in whatever } \\
\text { shape or form it comes (e.g., teaching, research, } \\
\text { management/administration) }\end{array}$ & 2.77 & 4.48 & 3.64 & 4.77 & $58.27 * * *$ & $\mathrm{AC}<\mathrm{PSMS}<\mathrm{ACL}=\mathrm{PSL}$ \\
\hline COL5 & $\begin{array}{l}\text { My institution provides constant opportunities for learning and } \\
\text { development }\end{array}$ & 3.92 & 5.16 & 4.65 & 5.20 & $31.68 * * *$ & $\mathrm{AC}<\mathrm{PSMS}<\mathrm{ACL}=\mathrm{PSL}$ \\
\hline COL6 & $\begin{array}{l}\text { In my institution staff have a lot of autonomy to choose how they meet } \\
\text { their output goals in whatever way they think is best }\end{array}$ & 3.71 & 4.43 & 4.26 & 4.72 & $14.69 * * *$ & $\mathrm{AC}<\mathrm{PSMS}<\mathrm{ACL}=\mathrm{PSL}$ \\
\hline \multicolumn{8}{|c|}{ Positive Well-being } \\
\hline PWB1 & I feel alive and vital at work & 3.90 & 5.45 & 3.85 & 5.66 & $45.95 * * *$ & $\mathrm{PSMS}=\mathrm{AC}<\mathrm{ACL}=\mathrm{PSL}$ \\
\hline PWB2 & I have energy and spirit at work & 4.22 & 5.71 & 4.19 & 5.73 & $41.75 * * *$ & $\mathrm{PSMS}=\mathrm{AC}<\mathrm{ACL}=\mathrm{PSL}$ \\
\hline PWB3 & I feel alert and awake at work & 4.57 & 5.78 & 4.42 & 5.77 & $35.77 * * *$ & $\mathrm{PSMS}=\mathrm{AC}<\mathrm{PSL}=\mathrm{ACL}$ \\
\hline PWB4 & I am looking forward to each new day at work & 3.55 & 5.09 & 3.63 & 5.09 & $39.43 * * *$ & $\mathrm{PSMS}=\mathrm{AC}<\mathrm{PSL}=\mathrm{ACL}$ \\
\hline \multicolumn{8}{|c|}{ Negative Well-being } \\
\hline NWB1 & Ifeel stressed at work & 5.15 & 4.31 & 4.53 & 3.86 & $21.05 * * *$ & $\mathrm{PSL}<\mathrm{ACL}=\mathrm{PSMS}<\mathrm{AC}$ \\
\hline
\end{tabular}


TABLE B: Results of the measurement models across groups of employment roles

\begin{tabular}{|c|c|c|c|c|c|c|c|c|c|c|c|c|c|c|c|c|c|c|c|c|c|c|c|c|c|c|c|c|c|c|}
\hline & \multirow{2}{*}{\multicolumn{3}{|c|}{$\begin{array}{l}\text { Total Sample } \\
\text { Complete M. M. }\end{array}$}} & \multirow{2}{*}{\multicolumn{3}{|c|}{ Reduced M. M. }} & \multicolumn{6}{|c|}{ Academic (AC) } & \multicolumn{6}{|c|}{ Academic Leader (ACL) } & \multicolumn{6}{|c|}{ Professionals Services (PS) } & \multicolumn{6}{|c|}{ Professional Services Leader (PSL) } \\
\hline & & & & & & & \multicolumn{3}{|c|}{ Complete M. M. } & \multicolumn{3}{|c|}{ Reduced M. M. } & \multicolumn{3}{|c|}{ Complete M. M. } & \multicolumn{3}{|c|}{ Reduced M. M. } & \multicolumn{3}{|c|}{ Complete M. M. } & \multicolumn{3}{|c|}{ Reduced M. M. } & \multicolumn{3}{|c|}{ Complete M. M. } & \multicolumn{3}{|c|}{ Reduced M. M. } \\
\hline & $\lambda^{*}$ & $\mathbf{R}^{2}$ & $\boldsymbol{R}$. & $\lambda^{*}$ & $\mathbf{R}^{2}$ & $\boldsymbol{R}$. & $\lambda^{*}$ & $\mathbf{R}^{2}$ & $\boldsymbol{R}$. & $\lambda^{*}$ & $\mathbf{R}^{2}$ & $\boldsymbol{R}$. & $\lambda^{*}$ & $\mathbf{R}^{2}$ & $\boldsymbol{R}$. & $\lambda^{*}$ & $\mathbf{R}^{2}$ & $\boldsymbol{R}$. & $\lambda^{*}$ & $\mathbf{R}^{2}$ & $\boldsymbol{R}$. & $\lambda^{*}$ & $\mathbf{R}^{2}$ & $\boldsymbol{R}$. & $\lambda^{*}$ & $\mathbf{R}^{2}$ & $\boldsymbol{R}$. & $\lambda^{*}$ & $\mathbf{R}^{2}$ & $\boldsymbol{R}$. \\
\hline \multicolumn{31}{|l|}{ Control } \\
\hline CON1 & .82 & .67 & .68 & .90 & .81 & .83 & .76 & .58 & .68 & .94 & .79 & .82 & .84 & .71 & .70 & .81 & .66 & .79 & .83 & .69 & .67 & .87 & .76 & .83 & .84 & .71 & .48 & .86 & .74 & .90 \\
\hline $\mathrm{CON} 2$ & .87 & .76 & .60 & .79 & .62 & .85 & .92 & .85 & .60 & .75 & .79 & .85 & .77 & .59 & .61 & .80 & .64 & .81 & .85 & .72 & .59 & .82 & .67 & .85 & .97 & .94 & .53 & .95 & .90 & .91 \\
\hline CON3 & .41 & .17 & .42 & & & .72 & .39 & .15 & .42 & & & .79 & .41 & .17 & .41 & & & .65 & .41 & .17 & .41 & & & .71 & .19 & .04 & .42 & & & .82 \\
\hline CON4 & .30 & .09 & & & & & .34 & .12 & & & & & .41 & .17 & & & & & .26 & .07 & & & & & .12 & .01 & & & & \\
\hline \multicolumn{31}{|l|}{ Collegial } \\
\hline $\begin{array}{l}\text { Governance } \\
\text { COL1 }\end{array}$ & .78 & .61 & .88 & .77 & .59 & .89 & .75 & .56 & .87 & .74 & .55 & .87 & .77 & .59 & .84 & .76 & .58 & .87 & .70 & .49 & .83 & .70 & .49 & .85 & .61 & .37 & .84 & .61 & .37 & .86 \\
\hline COL2 & .81 & .66 & .74 & .81 & .66 & .78 & .77 & .59 & .72 & .78 & .61 & .75 & .81 & .66 & .68 & .81 & .66 & .76 & .79 & .62 & .67 & .80 & .64 & .74 & .76 & .58 & .68 & .76 & .58 & .75 \\
\hline COL3 & .81 & .66 & .56 & .80 & .64 & .61 & .78 & .61 & .53 & .77 & .59 & .57 & .79 & .62 & .50 & .79 & .62 & .58 & .70 & .49 & .47 & .70 & .49 & .56 & .87 & .76 & .49 & .86 & .74 & .57 \\
\hline COLA & .83 & .69 & & .83 & .69 & & .79 & .62 & & .80 & .64 & & .74 & .55 & & .74 & .55 & & .82 & .67 & & .83 & .69 & & .81 & .66 & & .82 & .67 & \\
\hline $\mathrm{CO}$ & .71 & .50 & & .70 & .49 & & .67 & .45 & & .68 & .46 & & .69 & .48 & & .69 & .48 & & .66 & .44 & & .69 & .48 & & .69 & .48 & & .69 & .48 & \\
\hline COL6 & .52 & .27 & & & & & .58 & .34 & & & & & .30 & .09 & & & & & .34 & .12 & & & & & .34 & .12 & & & & \\
\hline Positive & & & & & & & & & & & & & & & & & & & & & & & & & & & & & & \\
\hline Well-being & & & & & & & & & & & & & & & & & & & & & & & & & & & & & & \\
\hline PWB1 & .92 & .85 & .92 & .92 & .85 & .90 & .90 & .81 & .90 & .90 & .81 & .90 & .90 & .81 & .90 & .90 & .81 & .90 & .92 & .85 & .91 & .92 & .85 & .91 & .94 & .88 & .90 & .94 & .88 & .90 \\
\hline PWB & .93 & .86 & .86 & .93 & .86 & .86 & .93 & .86 & .84 & .93 & .86 & .84 & .91 & .83 & .84 & .91 & .83 & .84 & .93 & .86 & .85 & .93 & .86 & .85 & .76 & .58 & .84 & .76 & .58 & .84 \\
\hline PWB & .78 & .61 & .75 & .78 & .61 & .75 & .74 & .55 & .71 & .74 & .55 & .71 & .71 & .50 & .72 & .71 & .50 & .72 & .77 & .59 & .73 & .77 & .59 & .73 & .88 & .77 & .71 & .88 & .77 & .71 \\
\hline PWB4 & .82 & .67 & & .82 & .67 & & .78 & .61 & & .78 & .61 & & .85 & .72 & & .85 & .72 & & .79 & .62 & & .79 & .62 & & .79 & .62 & & .79 & .62 & \\
\hline Negative & & & & & & & & & & & & & & & & & & & & & & & & & & & & & & \\
\hline Well-b & & & & & & & & & & & & & & & & & & & & & & & & & & & & & & \\
\hline $\mathrm{N}$ & 1.00 & - & - & 1.00 & - & - & 1.00 & - & - & 1.00 & - & - & 1.00 & - & - & 1.00 & - & - & 1.00 & - & - & 1.00 & - & - & 1.00 & - & - & 1.00 & - & - \\
\hline & $\chi^{2}[8$ & $=349.3$ & & $\chi^{2}[4$ & ]$=164$. & & $\chi^{2}[8$ & $\mathrm{J}=219.5$ & & $\chi^{2}[4$ & $\bar{l}=111.0$ & & $\chi^{2}[85$ & $\mathrm{j}=127.9$ & & $\chi^{2}[4$ & ]$=56.7$ & & $\chi^{2}[8$ & ]$=194.8$ & & $\chi^{2}$ & ]$=117$. & & $\chi^{2}[85$ & $=140.3$ & & $\chi^{2}[$ & ]$=52.7$ & \\
\hline Goodness of & RMS & $A=.06$ & & RMS & $\mathrm{EA}=.05$ & & RMS & $\mathrm{EA}=.05$ & & RMS & $\mathrm{EA}=.05$ & & RMS & $\mathrm{E}=.06$ & & RMS & $\mathrm{EA}=.03$ & & RMS & $\mathrm{EA}=.08$ & & RMS & $\mathrm{EA}=.08$ & & RMS & $\mathrm{A}=.10$ & & $\mathrm{RM}$ & $\mathrm{EA}=.03$ & \\
\hline & SRM & $=.06$ & & SRM & $\mathrm{R}=.03$ & & SRM & $R=.06$ & & SRM & $\mathrm{R}=.03$ & & SRM & $R=.07$ & & SRM & $\mathrm{R}=.04$ & & SRM & $R=.06$ & & SRM & $R=.05$ & & SRM & $\mathrm{R}=.09$ & & & $\mathrm{R}=.07$ & \\
\hline & $\mathrm{CFI}=$ & & & $\mathrm{CFI}=$ & & & $\mathrm{CFI}=$ & & & $\mathrm{CFI}=$ & & & $\mathrm{CFI}=$ & & & $\mathrm{CFI}=$ & & & $\mathrm{CFI}=$ & & & $\mathrm{CFI}=$ & & & $\mathrm{CFI}=$ & & & CFI & & \\
\hline $\begin{array}{l}\text { Correlations } \\
\text { Reduced } \\
\text { M.M. }(\Phi)\end{array}$ & $\begin{array}{l}\text { Cont } \\
\text { OG }\end{array}$ & & $\begin{array}{l}\text { Colle } \\
\text { OG }\end{array}$ & & $\begin{array}{l}\text { Positi } \\
W\end{array}$ & & $\begin{array}{l}\text { Cont } \\
\text { OG }\end{array}$ & & $\begin{array}{l}\text { Colle } \\
\text { OG }\end{array}$ & & $\begin{array}{l}\text { Positiv } \\
W\end{array}$ & & $\begin{array}{l}\text { Cont } \\
\text { OG }\end{array}$ & & $\begin{array}{l}\text { Colle } \\
\text { OG }\end{array}$ & gial & $\begin{array}{l}\text { Positiv } \\
W\end{array}$ & & $\begin{array}{l}\text { Cont } \\
\text { OG }\end{array}$ & & $\begin{array}{l}\text { Colle } \\
\text { OG }\end{array}$ & & $\begin{array}{l}\text { Positi } \\
W\end{array}$ & & $\begin{array}{l}\text { Cont } \\
\text { OG }\end{array}$ & & $\begin{array}{l}\text { Colle } \\
\text { OG }\end{array}$ & & $\begin{array}{l}\text { Positi } \\
W\end{array}$ & \\
\hline Collegi & $.44 * *$ & & & & & & $.22^{* *}$ & & & & & & $.73 *$ & & & & & & $.70^{* *}$ & & & & & & .70 ** & & & & & \\
\hline Posi & $.28 * *$ & & $.60 * *$ & & & & $.07 *$ & & $.54 * *$ & & & & $.32 * *$ & & $.61 * *$ & & & & .37 & & .57 ** & & & & .16 & & $.47 * *$ & & & \\
\hline Negative $W$ & $-.07 *$ & & $-.39 *$ & & $-.38 *$ & & $.10^{* *}$ & & $-.34 *$ & & $-.37 * *$ & & -.01 & & $-.26^{*}$ & & $-.40 * *$ & & $-.17 *$ & & $-.36^{*}$ & & $-.28 *$ & & -.01 & & -.11 & & $-.20 *$ & \\
\hline
\end{tabular}

R. Reliability of the latent variables: Cronbach's a/CRC/ AVE are located in the R column of each group. Complete M. M.: Complete Measurement Model and Reduced M. M.: Reduced Measurement Model: without CON3, CON4 and COL6. 
TABLE C: Determinants of well-being in the total sample

\begin{tabular}{|c|c|c|c|}
\hline Direct Effects & $\boldsymbol{\beta}^{\text {Model_I }}$ & $\boldsymbol{\beta}^{\text {Model_2 }}$ & $\boldsymbol{\beta}^{\text {Model_3 }}$ \\
\hline Respondents' gender (Female) $\rightarrow$ Positive Well-being & -.04 & .02 & .02 \\
\hline Respondents' age $\rightarrow$ Positive Well-being & $.09 * *$ & .02 & .04 \\
\hline Respondents' employment contract (Part time) $\rightarrow$ Positive Well-being & .00 & .06 & .05 \\
\hline $\begin{array}{l}P G \_B: \text { All other institutions with research income of } 22 \% \text { or more of } \\
\text { total } \rightarrow \text { Positive Well-being }\end{array}$ & .05 & .04 & .02 \\
\hline $\begin{array}{l}P G \_C: \text { Institutions with research income } 8-21 \% \text { of total } \rightarrow \text { Positive Well- } \\
\text { being }\end{array}$ & .02 & .01 & .01 \\
\hline $\begin{array}{l}P G_{-} D \text { : Institutions with research income } 5-8 \% \text { of total and total income } \\
>£ 120 m \rightarrow \text { Positive Well-being }\end{array}$ & -.01 & -.01 & -.04 \\
\hline $\begin{array}{l}P G \_E \text { : Teaching institutions with a turnover of } £ 40 m-£ 119 m \rightarrow \text { Positive } \\
\text { Well-being }\end{array}$ & -.05 & -.04 & -.00 \\
\hline$P G \_F:$ Smaller teaching institutions $\rightarrow$ Positive Well-being & .05 & .05 & .02 \\
\hline$P G_{-} G$ : Specialist music/arts teaching institutions $\rightarrow$ Positive Well-being & .03 & .02 & .00 \\
\hline Academic Leader $\rightarrow$ Positive Well-being & & $.32 * * *$ & $.10^{* * * *}$ \\
\hline Professional Services Manager-Support $\rightarrow$ Positive Well-being & & -.01 & -.01 \\
\hline Professional Services Leader $\rightarrow$ Positive Well-being & & $.24 * * *$ & $.06 * *$ \\
\hline Control Governance $\rightarrow$ Positive Well-being & & & -.01 \\
\hline Collegial Governance $\rightarrow$ Positive Well-being & & & $.58 * * *$ \\
\hline Respondents'gender (Female) $\rightarrow$ Negative Well-being & $.08 * *$ & $.09 * *$ & $.07 * *$ \\
\hline Respondents' age $\rightarrow$ Negative Well-being & -.04 & -.04 & -.04 \\
\hline Respondents' employment contract (Part time) $\rightarrow$ Negative Well-being & -.05 & -.08 & -.06 \\
\hline $\begin{array}{l}P G \_B: \text { All other institutions with research income of } 22 \% \text { or more of } \\
\text { total } \rightarrow \text { Negative Well-being }\end{array}$ & -.02 & -.02 & .00 \\
\hline $\begin{array}{l}P G \_C: \text { Institutions with research income } 8-21 \% \text { of total } \rightarrow \text { Negative Well- } \\
\text { being }\end{array}$ & .00 & .00 & .00 \\
\hline $\begin{array}{l}P G \_D: \text { Institutions with research income } 5-8 \% \text { of total and total income } \\
>£ 120 m \rightarrow \text { Negative Well-being }\end{array}$ & .00 & .01 & .04 \\
\hline $\begin{array}{l}P G \_ \text {E: Teaching institutions with a turnover of } £ 40 m-£ 119 m \rightarrow \text { Negative } \\
\text { Well-being }\end{array}$ & -.05 & -.04 & -.02 \\
\hline$P G \_F:$ Smaller teaching institutions $\rightarrow$ Negative Well-being & -.08 & -.09 & -.06 \\
\hline$P G_{-} G:$ Specialist musiclarts teaching institutions $\rightarrow$ Negative Well-being & -.00 & -.02 & .02 \\
\hline Academic Leader $\rightarrow$ Negative Well-being & & $-.17 * * *$ & $-.05 *$ \\
\hline Professional Services Manager-Support $\rightarrow$ Negative Well-being & & $-.17 * * *$ & $-.07 * *$ \\
\hline Professional Services Leader $\rightarrow$ Negative Well-being & & $-.19 * *$ & $-.08 * *$ \\
\hline Control Governance $\rightarrow$ Negative Well-being & & & $.10 * * *$ \\
\hline Collegial Governance $\rightarrow$ Negative Well-being & & & $-.39 * * *$ \\
\hline $\boldsymbol{R}^{2}$ Positive Well-being & .02 & .15 & .41 \\
\hline $\boldsymbol{R}^{2}{ }_{\text {Negative Well-being }}$ & .02 & .09 & .19 \\
\hline
\end{tabular}

$\boldsymbol{\beta}$ : Standardized coefficients.

$\boldsymbol{\beta}:$ Standardized coefficients.
$* * * p<.001 ; * * p<.05 ; * p<.10$.

Respondents' gender - group control: "Male".

Respondents' employment contract - group control: "Full time",

Employment role - group control: "Academic".

University Peer Group - group control: "PER_A: Russell group (excluding LSE)".

Model_1: $\chi^{2}[32]=97.50$, RMSEA $=.05$, SRMR $=.02$ and CFI=.98.

Model_2: $\chi^{2}[41]=110.74$, RMSEA $=.04$, SRMR $=.01$ and CFI $=.98$

Extended Model: $\chi^{2}[145]=355.54$, RMSEA $=.04$, SRMR $=.02$ and CFI=.97. 